\title{
A Polaridade como Referência na Concepção Intervalar de Almeida Prado na Sonata № 3 para Piano
}

\author{
The Polarity as Reference in the Interval Conception \\ of Almeida Prado's Third Piano Sonata
}

\author{
Edson Hansen Sant'Ana \\ Instituto Federal de Educação, Ciência e Tecnologia de Mato Grosso \\ edhansen_2000@hotmail.com
}

\begin{abstract}
Resumo: Este texto apresenta um estudo teórico-histórico da ideia de polaridade, levando em conta também os já pensados e discutidos conceitos controvertidos de consonâncias e dissonâncias, no entanto, sem descartá-los, busca desenvolver as tangências conceituais entre teorias aparentemente díspares (ex.: polaridade de Costère e interval class de Forte). Poder-se-á verificar que os teóricos abordados podem oferecer indicativos dessa tangência ao tratar da polaridade, principalmente da maneira como a resolutividade polar (cardinalidade) intervalar pode e tem sido resolvida na música do século XX. Paralelamente, quanto ao fenômeno de valorização da 'dissonância dura', especificamente a partir de estudos anteriores de outras obras de Almeida Prado, construo uma abordagem analítica intervalar que realça o termo 'expressividade intervalar', cunhado pelo próprio compositor. Este conceito alcança, todavia, uma superação terminológica em direção ao que tenho chamado de 'intervalo característico' - a tradução do fenômeno de recorrência intervalo-estrutural contrastante, de intervalos com maior potencial de dissonância aos intervalos iniciais da série harmônica. Tal organização tem ampla ocorrência nas composições pós-ruptura de Almeida Prado. Como estudo de caso, tomo a Sonata № 3 para piano, para exemplificar a construção intervalar que é recorrente em obras que pertençam às fases Pós-Tonal, Síntese e Pós-Moderna de Almeida Prado.
\end{abstract}

Palavras-chave: intervalo característico; teorias intervalares; polaridade no século XX; fases pósruptura de Almeida Prado.

\begin{abstract}
This text presents a theoretical-historical study of the idea of polarity, taking into account also the already thought and discussed controversial concepts of consonances and dissonances, nevertheless, without discarding them, it tries to develop the conceptual tangencies between apparently disparate theories (ex.: polarity of Costère and Forte's interval class). It can be seen that the theorists that I quote can offer indicatives of this tangency when dealing with polarity, especially in the way that polar interval cardinality can and has been solved in tw entiethcentury music. At the same time, in relation to the phenomenon of valorization of 'hard dissonance', specifically from previous studies of other works by Almeida Prado, I construct an
\end{abstract}


interval analytic approach that emphasizes the term 'intervallic expressivity', coined by the composer himself. This concept achieves, how ever, a terminological breakthrough tow ards what I have called the 'characteristic interval' - the translation of the phenomenon of contrasting interval-structural recurrence, from intervals with greater dissonance potential to the initial intervals of the harmonic series. Such organization has large occurrence in the post-rupture compositions of Almeida Prado. As a study case, I analyze the Third Piano Sonata, to exemplify the interval construction that is recurrent in works that belong to the Post-Tonal, Synthesis and Post-Modern phases of Almeida Prado.

Keywords: characteristic interval; interval theories; polarity in the Twentieth-Century; postrupture phases of Almeida Prado.

\section{1 - Introdução}

O percurso de entendimento das possibilidades intervalares também passou pela menção do cromatismo como gérmen causador da implosão da tonalidade. Nesse sentido, as sementes lançadas aqui e ali por Beethoven (17701827) em suas últimas Sonatas op. 109 a $111^{1}$ e depois mais ostensivamente por Wagner (1813-1883) em Tristão e Isolda (1857) utilizaram algum tipo de mudança intervalar para ampliação do âmbito sonoro em seus contextos composicionais. Esses compositores e obras poderiam ser definidos como o início das justificativas de importância em torno dos intervalos potenciais de 'outra sensibilização' da polaridade. Em Beethoven, essa iniciação de 'outra sensibilização', como uma energia potencial, ampliou-se em um cromatismo primário ainda com fins harmônicos, o qual não deixou de ter uma ação melódica, que em conjunto com seu tratamento harmônico estiveram ainda vinculados ao centro tonal. Onde a mesma energia potencial que outrora garantiria a coerência interna do sistema tonal pela pontuação cadencial em Beethoven, em fins do Romantismo, essa mesma sensível passou a ocorrer em contextos harmônicos onde ela normalmente não estaria. Assim, a realocação da sensível proporcionaria ferramentas para a desconstrução desse sistema tonal vigente (Bent e Pople 2001, p. 547-548).

Sabemos que esse conjunto de superações wagnerianas em Tristão e Isolda não teve uma teoria premeditada por parte de Wagner, mas que sua busca foi realizar a expressão máxima da relação entre o texto e a música dentro de seu conceito de música em sua arte total (Gesamtkunstwerk). Observa-se que em outras obras houve um comedimento cromático, comprovando assim que o

\footnotetext{
1 “Dentro de uma perspectiva moderna, a 'última trilogia de sonat as' junto aos últimos quartetos, se assemelha mais a uma geração posterior, de Schumann e Mendelssohn que a seu próprio tempo" (Rosen 2005, p. 283 apud Ribeiro 2009, p. 16).
} 
mesmo serviu a uma utilização que visaria às necessidades circunstanciais da representação, enredo e drama.

Segundo Matthew Woolhouse (2012, p. 1142), em Wagner haveria uma profícua 'harmonia funcionalmente ambígua' (functionally ambiguous harmony) suscitada pelo seu cromatismo. Uma ação germinativa desse processo intervalar se pode observar no exemplo abaixo de Tristão e Isolda. A partir desse excerto, podem ser observadas as relações de semitons ${ }^{2}$ nos planos diacrônicos.

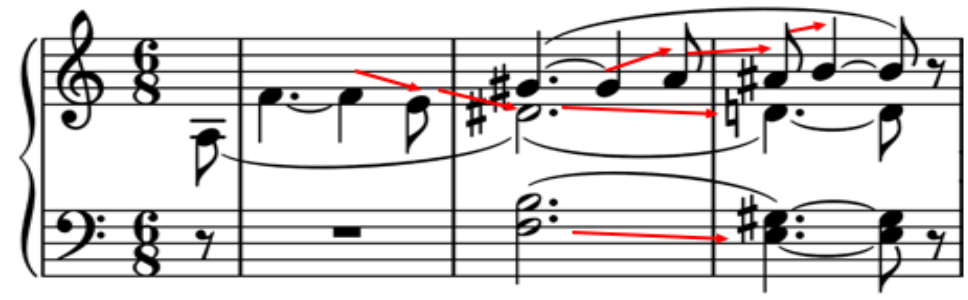

Exemplo 1 - A sensibilização da segunda menor na construção da funcionalidade harmônica ambígua em Tristão e Isolda de Wagner

Não somente Tristão e Isolda faria parte das peças representativas do caminho inovador surgido em fins do século XIX, no entanto essa obra tem representado a ideia da renovação e reestruturação como principal referência entre outras várias obras e compositores. Como se sabe, esse movimento gradual foi contínuo. Outras peças foram sendo agregadas a esse repertório, sucedendose uma a uma no arco da história de inovação. Poder-se-ia, como muitos teóricosmusicólogos o fizeram, incluir nessa trajetória o Prélude à l'après-midi d'un faune de Claude Debussy (1862-1918). Essa seria uma obra transitiva de considerável importância nesse percurso. Essa diacronia histórico-musical prosseguiu com Le Sacre du printemps de Igor Stravinsky (1882-1971) que incorporou a missão de ampliar avanços estéticos e sonoros. A tradução do que pôde significar a revolução musical da época seria materializada através da impressão do próprio Debussy sobre a Sagração de Stravinsky: "A Sagração perturba-me. Parece-me que Stravinsky está querendo fazer música com meios não-musicais" (Ansermet apud White, 1979).

\section{2 - A Polaridade como Referência: uma Fundamentação}

Sobre um dos aspectos da renovação melódico-intervalar, Matheus Bitondi (2006, p. 55-56), em um estudo de análise melódica (motívica) das peças

2 Simonsen (2011, p. 38-39) diz que: “é através das progressões por semitons que Wagner concretiza a revolução harmônica de Tristão e Isolda, cujo ponto culminanteé o início da seção da noite no dueto do segundo ato O sink hernieder, Nacht der Liebe". 
In Freundschaft (de Stockhausen), Sequenza IXa (de Berio), Dialogue de l'ombre double (de Boulez) e Madrigal I (de Pousseur), afirmou que ela "é um fato que poderia ser interpretado como um traço estilístico comum a várias correntes composicionais surgidas no século $X X$ e vinculadas ao que se convencionou chamar de atonalismo". Ele disse que o padrão intervalar "de alguns dos motivos estruturalmente mais importantes nestas peças parece obedecer a uma regra comum que poderia ser formulada da seguinte maneira: a um dado intervalo, segue-se outro em direção oposta que, em relação ao primeiro, é maior [mais agudo] ou menor [mais grave] em um semitom". Se Bitondi falou do intervalo de meio tom como referência para a música atonal na direcionalidade horizontal, ele (o intervalo) entendeu-se histórico-composicionalmente e foi na verticalização da harmonia que o referido intervalo ganhou sua liberdade e consolidação de uso estético e poético. Relembre-se a referência que Pousseur faz à 'simultaneida de', já proferida anteriormente por Schoenberg, como a 'emancipação da dissonância'. Estas denominações puderam ser estabelecidas como conceitos que argumentaram a prominência da sincronicidade desse intervalo e seus correlativos.

Voltando ao plano diacrônico, Pousseur (2009, p. 53) quando se referiu a Schoenberg (Op.19, I) em comparação a Webern, afirmou que "as justaposições cromáticas se dão por semitom" e isso é uma obviedade do ponto de vista da horizontalidade melódica. No entanto atente-se para a explicação abaixo de Pousseur, associando mais dois tipos intervalares com o semitom. Pousseur fez menção aos "intervalos cromáticos sucessivos mais extensos que o semitom", os intervalos de nona menor e sétima maior, e disse que "apresentam-se como formas distendidas, particularmente expressivas, mas nem por isso menos condutoras do semitom".

Também ao referir-se à disposição direcional "que é de fundamental importância", sobre o aspecto harmônico do cromatismo e seus intervalos - "o estudo da estrutura das relações sonoras simultâneas (verticais) e seus encadeamentos" - Pousseur (2009, p. 54) analisou o Op. 19, I de Schoenberg e afirmou que

naturalmente, tem-se aqui, de novo, a presença de numerosos intervalos cromáticos, expostos desta vez sob a forma de sétimas maiores. Todavia, eles encontram-se em grande parte resolvidos (precisamente por meio de uma das locomoções de meio-tom, cuja abundância havíamos assinalado acima), seja numa consonância, seja numa dissonância menos dura, menos tensa (ou seja, numa relação lógica menos complexa, com um grau de parentesco menos distante entre as frequências) (Pousseur 2009, p. 54).

Diversos compositores-teóricos produziram escritos com mais ou menos abrangência sobre os problemas intervalares. Assim, o assunto continuou (e continua) interessando muitas correntes de estudo e pensamento na música. 
Dessa maneira, a Set Theory oferece o conceito interval class (classe de intervalos) concebido a partir de Babbitt $(1960)^{3}$, sistematizados por Forte (1973) e propagados por Straus (1990), entre outros. Esse conceito unicamente e de maneira tangencial se mostrou útil para este estudo. Entretanto, considerou-se que a presente análise e seu escopo teórico somente se atrelaram a este aspecto emergente da Teoria dos Conjuntos, limitando-se a não avançar e nem utilizar a listagem das possibilidades dos conjuntos intervalares do Forte number. Para esta pesquisa, interessou introdutoriamente somente a classificação dos intervalos da Set Theory, não como instrumento analítico, mas como parte do suporte conceitual que contribuiria na construção teórica do que chamei de intervalo característico.

Apesar de na prática, para uma análise sob o viés da Set Theory, não se levar em conta em que oitava um determinado material (altura, intervalo e/ou acorde) aconteçam, tal consideração da oitava teria sua implicação direta sobre o conceito de ressonância, este também, em parte, vinculado à série harmônica. Sabe-se que os conceitos de 'consonância' e 'dissonância' guardam intrínseca ligação com as bases teóricas da série harmônica, pois na série harmônica os intervalos consonantes estariam perceptivamente mais próximos da fundamental (oitava justa, quinta justa, quarta justa, terça maior, terça menor). Nos mesmos termos, os intervalos mais distantes da fundamental são estabelecidos como intervalos dissonantes (sétima menor, segunda maior, segunda menor, sétima maior). A Set Theory substitui as representações perceptivas e descritivas da dissonância e da consonância da prática musical comum por sua própria representação que se denominou 'classe'. Não se considerando a 'classe 6' (trítono), todos os outros intervalos partiriam dos dissonantes para os consonantes (da esquerda, 'classe 1', para a direita, 'classe 5'.

A Set Theory quando construiu suas 'classes de intervalos', sendo tais classes em parte baseadas no conceito de dissonância, como relação primeira, as consonâncias secundarizadas (como exemplo, a 'classe 5' na extrema direita do quadro de Forte/Straus) caracterizam uma catalogação por hierarquia em ordem de importância físico-sonora. No quadro de classe intervalar (interval class), isso se deu primeiramente, em partes, pela própria organização intrínseca à série harmônica. Algumas ordens foram secundarizadas, como os intervalos da 'classe 5 ' e da 'classe 6'. A oitava justa foi excluída das classes de intervalos. A proeminência seria dada à dissonância, como representante do intervalo potencial de dureza, que confere ao repertório pós-tonal seu alcance sonoro na estética da música do século XX.

Sendo a oitava excluída dessas seis classes, poderia se subentender que ela seria uma possível 'classe 0 ' com uma correlação à classe de alturas/notas entre o

${ }^{3}$ Uma sistematização inicial do conceito conforme Forte (1973, p. 1). 
'0' como Dó e um '12' como um outro Dó na condição de oitava acima4 . Assim, a consonância seria relativizada no corpo da teoria, prevalecendo uma ordem privilegiada da dissonância dura (classe 1) e seus intervalos correlatos. Sãonesses termos que a interval class da Set Theory guardaria ligação com a série harmônica.

É claro que há uma existência inerente da oitava nesse sistema teórico, no entanto ela deixa de ter preponderância conceitual. E se a dissonância dura tem relevância em primeiro grau no campo da teoria, fale-se também que um intervalo de sétima maior da 'classe 1' tem 'virtude cromática' graças a sua subjacência de resolução que se encaminha à oitava. Conforme Pousseur, o intervalo deve sua existência à oitava. A 'classe de intervalos' no total cromático visa construir um tipo teórico que não mais privilegia a tonalidade, mesmo que não a rejeite. Há um ideal e um plano bem esquematizado para esta subvenção. Ainda assim, continuo vendo tangências importantes para uma inicial conjugação da 'classe 1' com os pensamentos de Costère e Pousseur quanto aos aspectos de 'polaridade' e 'multipolaridade' respectivamente.

\begin{tabular}{|c|c|c|c|c|c|c|}
\hline $\begin{array}{l}\text { Classe de } \\
\text { Intervalos }\end{array}$ & Cl 1 & Cl 2 & Cl 3 & $\mathrm{Cl} 4$ & Cl 5 & Cl 6 \\
\hline \multirow{2}{*}{$\begin{array}{c}\text { Intervalos } \\
\text { no Total } \\
\text { Cromático }\end{array}$} & \multirow{2}{*}{$\begin{array}{l}\text { 2a. } m \\
\text { 7a. } M \\
\text { 9a. } m\end{array}$} & 2a. $M$ & 3a. $\mathrm{m}$ & 3‥ M & 4a. J & 4a. aum \\
\hline & & 7ạ. $m$ & 6a. M & 6a. $\mathrm{m}$ & 5a. J & 5‥ $\operatorname{dim}$ \\
\hline
\end{tabular}

Tabela 1 - Classe de intervalos no total cromático (conforme Straus 2013, p. 11)

Através da classificação dos intervalos nesse quadro acima, observa-se o que já se comentou: a catalogação separa os mesmos por ordem de potência de dissonância (mais ou menos capacidade de polarização: devendo-se ater à distância discutível entre $\mathrm{Cl} 1$ e a $\mathrm{Cl} 6$ desse sistema teórico). É claro que a nomeação como 'dissonância' traz um termo conectado com questões do tonalismo que, por ora, traz desconforto mesmo que temporariamente (considerando-se tal termo com as ressalvas históricas já conhecidas). A dissonância é uma taxação inconsistente, e até mesmo dúbia, quando se fala em teorizações que envolvem outros sistemas musicais que não estejam atrelados ao tonalismo. Para Schoenberg, a 'dissonância' seria instável, ao mesmo passo que nem toda consonância é absolutamente estável e polar, como bem demonstrou no caso da neutralidade das terças e sextas (2001, p. 60). É importante lembrar que se uma segunda menor no plano sincrônico é caracterizada como 'dissonância', no plano diacrônico essa percepção desaparece, porque o intervalo se atrela às questões resolutivas da tonalidade quando tem a possibilidade da disposição melódica.

4 ‘ 0 ' igual a um Dó, ' 1 ' igual a Dó\# ou Réb... até ao '11' igual ao $\mathrm{Si}$, e um ‘12' igual ao Dó como hipotética oitava acima do ' 0 '. 
Entendendo-se a potencialidade histórica dos intervalos, Menezes disse que "num contexto rigorosamente tonal (digo, sistematicamente tonal), é preciso atentarmos para o grau de seu dinamismo interno, de sua potencialidade atrativa, de seu desenvolvimento com as leis acústicas da polarização seletiva" (Menezes 2002, p. 113-114). Persichetti (1985, p. 12) classificou os intervalos dos doze sons em seis classes: consonâncias abertas (quintas e oitavas justas), consonâncias brandas (terças e sextas [maiores e menores]), dissonâncias brandas (segundas maiores e sétimas menores), dissonâncias fortes (segundas menores e sétimas maiores) e duas classes restantes: consonância/dissonância (quarta justa) e o intervalo ambíguo do trítono ([neutro/instável]: quarta aumentada ou quinta diminuta). O quadro de Persichetti oferece a demonstração fenomenológica dos intervalos que este trabalho busca privilegiar quanto às dissonâncias fortes (ou duras). Observe-se o Exemplo 2 abaixo:

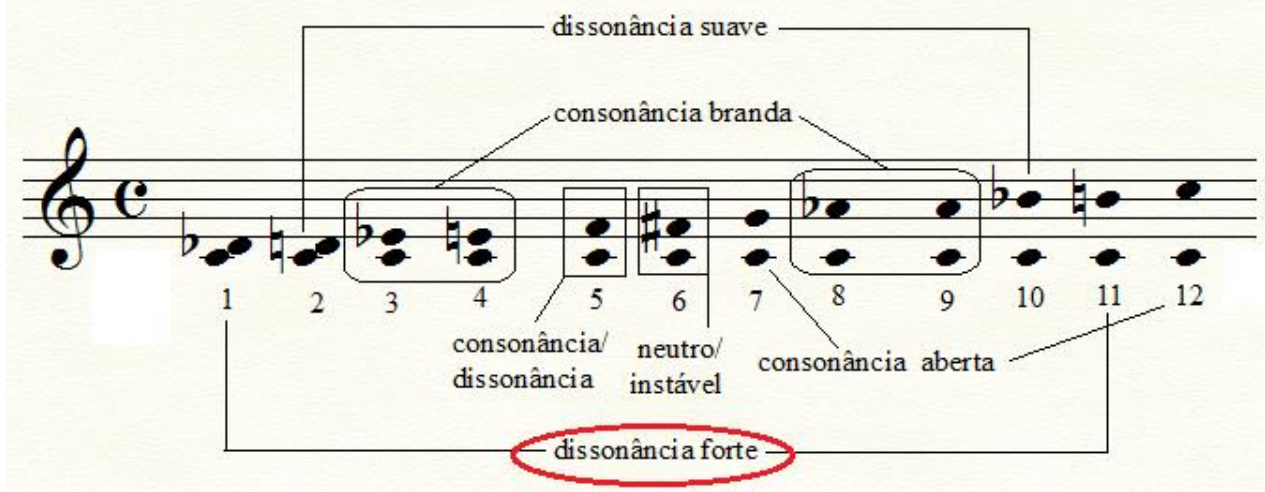

Exemplo 2 - Naturezas dos intervalos: dissonância e consonância. Realço as dissonâncias fortes, entendidas neste trabalho sob o conceito de intervalos característicos.

Segundo Persichetti, "os intervalos podem seguir uma ordem de um após outros, e podem ordenar-se para formar um modelo de ação recíproca e gradual da tensão". O autor fez a ressalva de que "a qualidade da quarta justa e do trítono se determinará somente pelo contexto" (Persichetti 1985, p. 13).

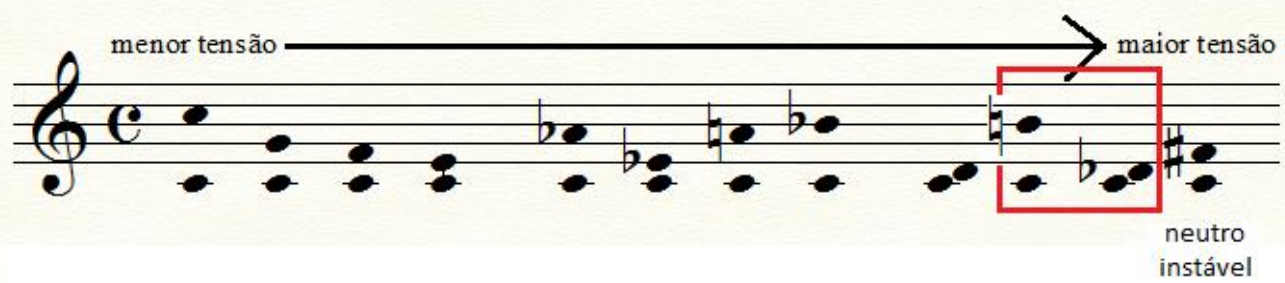

Exemplo 3 - Níveis de menor tensão à maior tensão: a natureza dos intervalos quanto aos níveis de menor à maior tensão. 
$\mathrm{Na}$ direção de se entender o potencial do intervalo, o conceito de 'polarização' foi desenvolvido por Costère (1954, 1962) como oriundo do esquema da série harmônica. Definiu também como 'intervalos polares' aqueles que contêm grande capacidade de atração. Costère desenvolveu a 'teoria das notas atrativas' delineando o conceito da polaridade em conjunto com o 'princípio da identidade dos sons na oitava' (Ramires 2009, p. 1-7). Bittencourt (1999, p.2) traduziu o pensamento de Costère e disse que, "apesar da multiplicidade de estilos musicais possíveis, Costère observava a existência de algo objetivo, físico-acústico e não cultural, subjetivo, capaz de gerar relações de polarização, de atração entre alturas, um princípio sempre ativo nas sonoridades". Na sua 'Lei de Atração Universal' estabeleceu 'as menores distâncias entre dois pontos' (isto é, duas alturas). Desta maneira, para Costère, cada classe-altura teria cinco 'atratores' chamados de 'notas cardinais':

1) A própria nota;

2) As quintas (justas ascendente e descendente): o menor caminho no sentido da série harmônica;

3) As duas alturas adjacentes às quintas (o menor caminho no sentido da escala), que podem variar de acordo com o temperamento usado e que se traduzem nos semitons ascendente e descendente (temperamento igual com doze notas por oitava).

Menezes, em seu livro Apoteose de Schoenberg, apresentou os cinco 'intervalos polares':

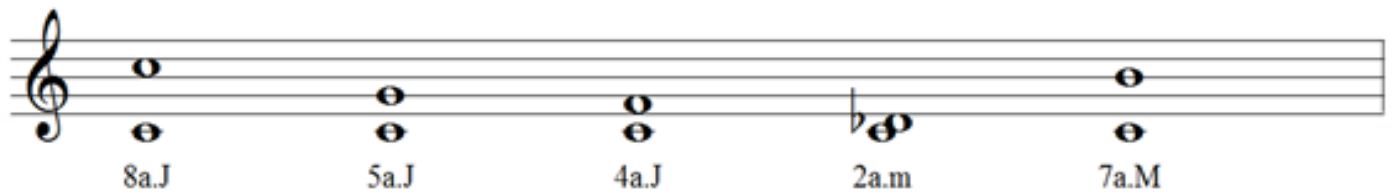

Exemplo 4 - Intervalos polares da teoria de Costère (conf. Menezes 2002, p. 104)

Nesse ponto, aproximando-se os 'intervalos polares' de Costère, descritos por Menezes (2002, p. 104), com a lógica da 'classe de intervalos' de Forte, e/ou às 'formas distendidas do semitom' de Pousseur (2009, p. 53), o desenho dos intervalos apontados por Costère passa pela inclusão do intervalo de nona menor (9a $\mathrm{m}$ ), por um mínimo artifício de ajuste de oitava acima de uma segunda menor. Dessa maneira, o implemento de Costère é perfeitamente associável ao interval class 1, o qual já teria a presença da nona menor como elemento natural a sua concepção teórica. 


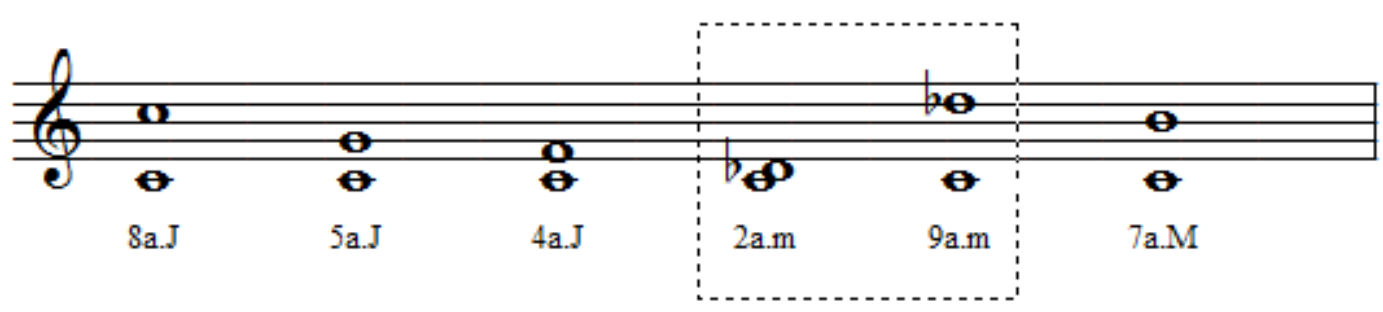

Exemplo 5 - Intervalo de $9^{\mathrm{a}} \mathrm{m}$ fazendo aproximação à concepção de Costère: tangências entre a concepção de Costère e à lógica da 'classe 1' da 'classe de intervalos' (interval class) de Forte e Straus.

Marisa Ramires, e, anteriormente outros pesquisadores associaram a teoria de Costère à Teoria dos Conjuntos. Entre eles, Marcus Bittencourt (1999) publicou Um modelo computacional das teorias de Edmond Costère e da Teoria de Conjuntos implementado em uma ferramenta analítica em PHP, no qual foi demonstrado teoricamente essa possibilidade. Ramires ${ }^{5}$, e a posteriori Coelho de Souza $^{6}$ fizeram observações à teoria de Costère. Embora Ramires faça alguma crítica pontual a Costère, a autora utilizou em uma de suas análises a associação da teoria de Costère à Teoria dos Conjuntos como proponho. Ainda assim, mesmo a despeito dessas ressalvas, as considerações discutidas anteriormente pelos autores supracitados endossam o papel da atratividade dos intervalos polares' da teoria.

Ainda na questão da polaridade, Rael Toffolo (2014, p. 31) afirma que "Pousseur propõe um estudo das polarizações intervalares que apresenta grande similaridade aos estudos de Edmond Costère [...]". Esse argumento apoiou-se nas proporções da série harmônica, e ele argumentou que "os intervalos serão caracterizados como mais consonantes ou mais dissonantes, ou seja, mais polares - maior poder de confirmação da fundamental - ou mais apolares, dependendo da posição que ocupam na série harmônica".

\footnotetext{
5 “Em momento algum Costère, no Lois et Styles des Harmonies Musicales ou mesmo no Mort ou Transfigurations de l'Harmonie, apresenta uma peça analisada na íntegra. Os trechos que ele analisa e comenta são curtos, apenas alguns compassos, e limitam-se a ilustrar um determinado enfoque abordado por sua exposição teórica. Assim, a interpretação dos resultados obtidos nas Tabelas Cardinal, Tonal e Transpositora permite classificar as gamas em diferentes aspectos e enfoques. Entretanto, comentários e justificativas sobre a adoção dos reforços, sobre os critérios de seleção dos escalonamentos, de interpretação dos resultados obtidos nas três tabela se suas consequências para o compasso, o trecho e a peça são escassos e pouco elucidativos" (Ramires 2001, p. 262).

6 "Costère nunca comprovou a validade de sua teoria confrontando-a com a prática analítica. As escassas tentativas que se conhece, como a de Ramires (p. 265-377 da obra citada) analisando o Opus 25 de Schoenberg, revelam os problemas eos pontos fracos da teoria de Costère, o que acaba resultando, ao contrário, numa demonstração da insuficiência conceitual da teoria" (Coelho de Souza 2009, p. 138).
} 
No Exemplo 6, Pousseur (2009, p. 198-199) demonstra a partir da seta centralizada para baixo, o local mais consonante das relações intervalares que ele organiza. Leve-se em conta que na direita, o intervalo de sétima mais que aumentada, fisicamente é o mesmo intervalo de oitava justa, repetindo-se assim, o mesmo índice de consonância do intervalo centralizado de oitava justa. À extrema esquerda, o intervalo de nona mais que diminuta, igualmente também é um intervalo físico de oitava justa.

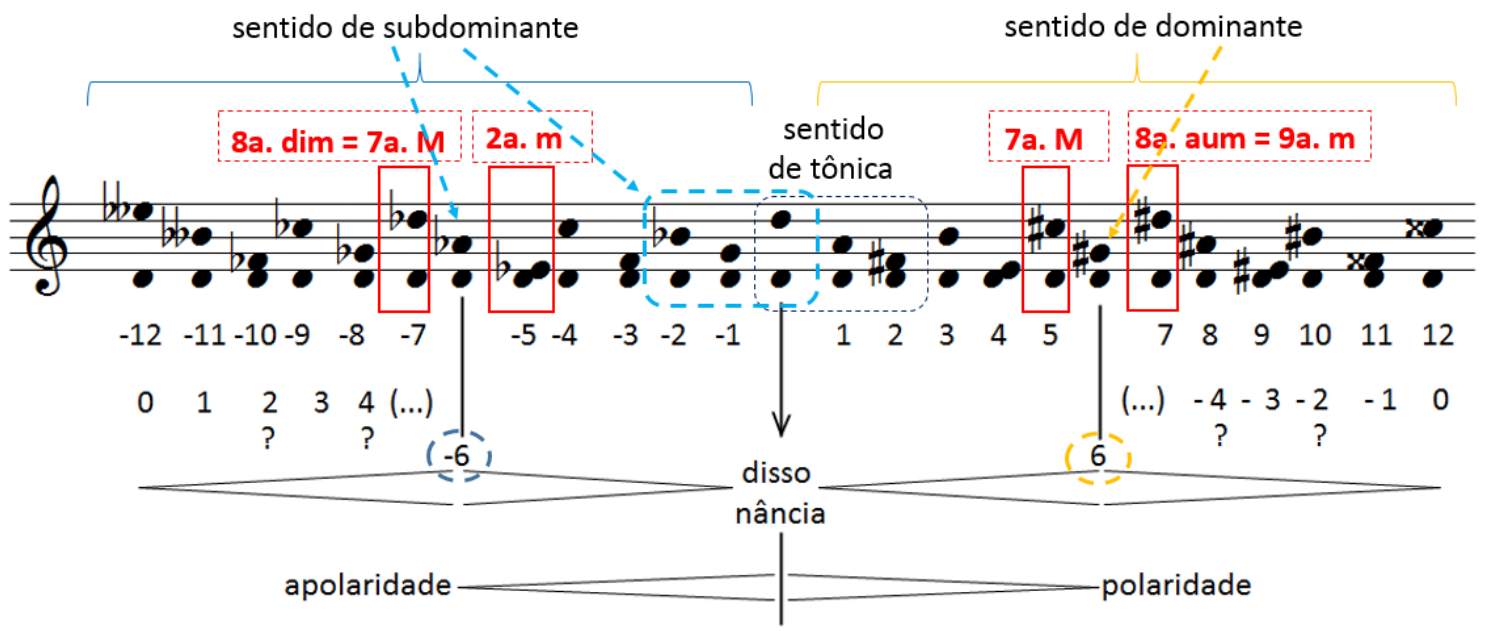

Exemplo 6 - A polaridade, a consonância e a dissonância dos intervalos (conf. Pousseur 2009, p. 198)

O centro da oitava justa (Ré3-Ré4) nomeia-se zero. À direita seguem-se os intervalos maiores (os intervalos 2, 3, 4 e 5), sustenizados (2, 5, 7, 8, 9, 10, 11 e 12), tendendo ao sentido de dominante, fazendo com que a nota mais grave (Ré3) se afirme em sua polaridade, mas que a partir da obtenção de um intervalo mais dissonante, essa polaridade intervalar se indefine. São doze intervalos à direita constituídos de consonantes, dissonantes e neutro (trítono - que dependerá de seu contexto harmônico). Todos intervalos à direita são construídos com sua altura superior, quando necessário, seguindo uma aplicação de sustenidos caminhando para uma cadenciação de uma 'dominante da dominante' para a dominante de Ré maior - explicando o caminho, ele é assim definido: o intervalo 6 sendo Ré e Sol\# (base da dominante da dominante) como trítono - cada uma das sensíveis - que resolve em Dó\# e Lá, que é base de uma tônica momentânea (Lá), mas que em essência é uma dominante de Ré maior).

Outra vez, relembrando que o intervalo central de oitava justa (Ré3-Ré4) é o ponto zero, à esquerda, seguem-se os intervalos menores (os intervalos -2, -3, 4 e -5), bemolizados (-2, -5, -7, -8, -9, -10, -11 e -12), tendendo ao sentido de subdominante, afirmando a polaridade da nota mais aguda do intervalo, embora a nota mais grave se 'infirme', conforme Pousseur diz, referindo-se à polaridade de base da nota Ré3. São doze intervalos à esquerda constituídos também de 
consonantes, dissonantes e neutro (trítono - que igualmente dependerá de seu contexto). Todos os intervalos à esquerda são constituídos com sua altura superior, quando necessário, seguindo a utilização de bemóis caminhando para uma cadenciação de uma subdominante relativa de Sol menor (Sib: seu trítono Ré e Láb resolvendo na subdominante da subdominante (Mib) considerando-se Ré menor (como centro) - explicando o caminho, ele é assim definido: o intervalo -6 sendo Ré e Láb (base de um trítono pertencente a subdominante relativa de Sol menor que é Sib7), tal trítono resolve em Mib e Sol que é base de uma outra subdominante (uma tônica momentânea), mas que em essência é uma subdominante (Mib) da subdominante relativa de Sol menor (Sib) que pertence a um Ré menor.

Em síntese, à direita, o intervalo seis (6) Ré3-Sol\#3 implicaria na resolução ao Dó\#3-Lá3 como intervalo base de um acorde de dominante (Lá maior) no centro de Ré (Ré maior com sentido de tônica). À esquerda, o intervalo -6, na sua altura mais aguda, o Láb3 tenderia ao Sol3 que seria a base para outros acordes com caráter de subdominante, no entanto a sugestão primária está em torno de Sol menor (-2, -1 e 0: como subdominante menor de Ré menor). À esquerda, o sentido de subdominante pode direcionar a outras possibilidades de subdominantes em parentesco como Sol menor sendo associado a um Sib maior e/ou outras correlações com sentido de subdominante.

Verifique-se que o quadro de Pousseur (2009, p. 198) traz à direita, perto do intervalo 6, como um trítono que na sua direita tem a oitava aumentada equivalendo à nona menor; e, a sua esquerda, o intervalo de sétima maior. Por outro lado, à esquerda, junto ao intervalo -6, à direita dele, o intervalo de segunda menor e a sua esquerda o intervalo de oitava diminuta equivalendo à sétima maior. As anotações nesses referidos intervalos buscaram apontar a carga de 'tensão' máxima dentro do ambiente do total cromático, os quais nos interessam neste estudo. Os intervalos 6 e o -6, na espécie de trítono, é lembrado por Perscihetti como intervalo instável ou neutro (podendo ou não, ser avaliado como intervalo de potência 'considerável' quanto à dissonância quando atrelado à dominante). Persichetti, Pousseur e Costère aproximam-se reciprocamente sem que se necessite fazer forçosos empreendimentos teóricos para concatená-los. As definições da polaridade e dos tipos de natureza sensível das consonâncias e dissonâncias estão conceitualmente aproximadas entre eles, porque todos se apropriam de construções baseadas no planejamento teórico a partir da série harmônica.

Pousseur ainda no seu livro Apoteose de Rameau, no seu segundo artigo De Schoenberg a Webern: uma mutação, diz que a música tonal integrou concentricamente a articulação $\mathrm{da}(\mathrm{s})$ sensível(is) "num complexo de relações muito mais simples (a cadência), subordinava-os a este último [complexo] e os deduzia de sua ordenação interna estritamente convergente" (Pousseur 2009, p. 
51). Nesse capítulo Pousseur buscou estudar as diferenças entre Schoenberg e Webern através de uma análise comparativa entre as obras Op. 19 e a Op. 5 respectivamente. Nesse estudo, Pousseur fez uma das mais importantes declarações e definições sobre 'multipolaridade', conceito que abriu um universo de entendimento muito mais claro para as obras dodecafônicas, que estariam em uma lógica expandida a partir do universo harmônico. Essa concepção, nesse sentido, se aproximou muito bem com a teorização de Schoenberg quando advogou não haver 'dissonância' e nem 'atonalidade'.

Para Pousseur, o universo 'multipolar' compreenderia uma 'contraposição à unipolaridade' das sensíveis a um centro tonal (um único e absoluto pólo). Para a música nova, a música admissível como 'atonal' ou outra nomeação que se queira dar, entendendo como aquela pertencente a um novo 'universo' histórico temporal do século $X X$, pode pensar-se que "todas as relações frequenciais - não somente as relações cromáticas, que garantiam sua integridade, mas também os intervalos originalmente mais simples, mais aparentemente diatônicos (quartas, terças, etc.) - encontram-se dotadas de uma estrutura, de uma significação doravante bipolar". Nas palavras de Pousseur, a partir de então, qualquer intervalo teria implícito nas suas alturas um potencial polar resolutivo para qualquer direção. A nova linguagem musical contemplaria uma equalização da tensão em todo o universo sonoro do total cromático (Pousseur 2009, p. 51).

Esse conceito de 'bipolaridade' ou 'multipolaridade' estaria estritamente ligado à definição do que se concebeu como 'harmonia de simultaneidade' (a verticalização das relações cromáticas: segundas menores, sétimas maiores e nonas menores) ". A definição de Pousseur materializa minha preocupação e percepção, ainda insurgentes, mas vigentes na pesquisa e análise empreendidas nos Dezesseis Poesilúdios de Almeida Prado durante o mestrado. Essa concepção de Pousseur já corroborava, muito anteriormente, em direção convergente ao meu enfoque, sem antes sequer que eu conhecesse as teorias de Pousseur. Assim, essa ampliação teórico-analítica de Pousseur quanto à polaridade, criando seu conceito magistral de 'multipolaridade', vinculou-se ao meu conceito teóricoanalítico quando manteve o olhar voltado a determinados intervalos. É concebível que o ouvido contemporâneo tenha se alargado naquele conceito de volatilidade do que é consonância e dissonância aventado por Boulanger (1926), mas, de alguma maneira podendo-se pleitear uma atenção analítica aos intervalos que são desdobramentos de uma segunda menor, classificando-os como 'dissonâncias duras'.

A partir de uma implementação de um modelo de cálculo de tensão harmônica, Toffolo (2014, p. 77-95) construiu uma série de experimentos com os intervalos de oitava justa, quinta justa, terça menor, trítono e os acordes prototípicos da Segunda Escola de Viena (p. 85-87). Foram incluídos nessa 
pesquisa de Toffolo os intervalos de segunda menor, sétima maior e nona menor. A respeito da segunda menor, ele escreveu:

Talvez um dos aspectos mais interessantes aqui seja que em ambos os quadros a Segunda Menor apresenta o mais alto grau de tensão, demonstrando sua instabilidade e seu poder de geração de movimento. Fica aqui caracterizado o poder polarizador da Segunda Menor como fenômeno de sensível, tal qual discorrem Costère, Menezes e outros. No caso da Segunda menor, todos os parciais harmônicos de uma das notas encontram-se em relação de segunda menor com os parciais da outra nota, justificando seu alto grau de tensão, propiciando a geração da necessidade de algum movimento para que haja a eliminação dessa tensão, que melodicamente ocorre quando o que se segue confirma a série harmônica de uma das notas. Quando as segundas menores ocorrem simultaneamente, há a polarização que aponta da mesma forma para cada um dos elementos do intervalo, ou, como afirma Menezes, "uma vez simultâneas, ambas as duas frequências que se inter-relacionam por meio-tom sensibilizam-se reciprocamente" (Menezes 2002, p. 114), fenômeno este tão importante para a música da Segunda Escola de Viena e que acarretou no desenvolvimento do conceito de harmonia de simultaneidade (Toffolo 2014, p. 85).

Assim, nessa direção, a área da Teoria e Análise Musical parece avançar a partir de concepções de outra área - a Composição - em que seus compositoresteóricos, como Pousseur e muitos outros, tem deixado suas contribuições valiosas. Há hoje um beneficiamento retroalimentado em uma prática compartilhada e interdisciplinar a partir de diferentes arcabouços teóricos, testando os pontos convergentes e divergentes entre si. Esse comportamento dos pesquisadores e seus campos diante do universo musical comprova os sintomas descritos por Paulo Lima (2011) em sua catalogação dos 'horizontes temáticos' da Teoria e Análise Musical, de que há constantes ajustes projetados entre as transdisciplinaridades de seus conhecimentos e conteúdos.

\section{A 'Expressividade Intervalar' entendida como 'Intervalo Característico': uma superação terminológica}

Minha tese é muito imprecisa nesses postulados. Ainda bem, por que há margem para um outro compositor continuar meu trabalho. (Prado e Moreira 2004, p. 75).

Após o processo da análise musical dos Dezesseis Poesilúdios, e das obras escolhidas para o conjunto mais abarcante desta pesquisa ${ }^{7}$ (a Sonata $N^{o} 3$ [fase

\footnotetext{
${ }^{7}$ Neste artigo é demonstrada somente a análise da Sonata $n .^{\circ}$ 3, portanto, não foram adicionadas as análises das Cartas Celestes I e do Noturno № 7.
} 
Pós-Tonal], as Cartas Celestes I [fase Síntese] e o Noturno № 7 [fase Pós-Moderna], tem sido seguro dizer que as verificações e os dados obtidos continuaram oferecendo uma direção plausível para reunir argumentos que solidificassem a existência de uma lógica intervalar na construção estrutural em Almeida Prado. Parece existir uma referência organizada das distâncias e uma ideia clara de que sua composição é alimentada pelo cuidado às mínimas constituições do parâmetro da altura no total cromático: os intervalos. Assim, a partir do presente estudo possibilitou-se continuar afirmando quais tipos de intervalos interessam recorrentemente a Almeida Prado.

Como parte do exercício teórico-metodológico, é importante relembrar minhas questões de pesquisa, recolocando a indagação principal que envolve a busca da compreensão da concepção intervalar como material organizado, consistente e recorrente. Em bases epistemológicas, seria coerente, e não contraditório o termo expressividade intervalar? Haveria necessidade de se construir ou substituir uma classificação/nomeação de um termo que abarcasse a concepção, a importância e a modelagem intervalar que são apontadas no processo analítico das obras de Almeida Prado?

O termo expressividade intervalar, forjado pelo próprio compositor (Prado e Nadai 2007, p. 9 e 117), foi ampliado e organizado em meu trabalho de mestrado (Sant'Ana 2009), como conceito explícito acionado e ordenado pelas preferências de certas distâncias entre as alturas (diacrônicas e sincrônicas) em sua estruturação composicional.

A 'expressividade intervalar' perpassa vários sistemas musicais - tonal, modal, atonal, serialismo livre e transtonalismo - tal vinculação ocorre por uma ordem de organizações intervalares, que fazem tais intervalos estar dentro de um sistema ou outro, ou na intersecção ou margem dos mesmos sistemas. Portanto essa ordem de padrões e recursividade define-se como a 'expressividade intervalar' com sentido ampliado e desenvolvido a partir do termo cunhado pelo próprio compositor (Sant'Ana 2009, p 14).

Cada tipo de intervalo possui capacidades qualitativas sonoras que indicam um maior ou menor 'nível de tensão' (Persichetti 1961, p. 11-20). Silvio Ferraz traz como exemplo a ideia de 'radiação sonora' na composição de Varèse (Hyperprism e Octandre), onde ele evidencia em 'sua escrita harmônica' a distinção dos "blocos tímbricos entre o efetivo de suas instrumentações. Harmonicam ente é dos intervalos de nona e sétima que falamos, do modo como se valia de certas dissonâncias para realçar batimentos e difusões instrumentais inusitadas, resultantes justamente de tais batimentos" (2002 p. 16, grifo nosso). Pousseur fala também de uma força atrativa dos referidos intervalos, em conjunto com a questão primária de dissonância, que propicia a eles as 'zonas de contato' (2009 p. 58), tornando tais intervalos em redutos de energia sonora. 
Conforme se observou, os compositores-teóricos, quando falam da potencialização desses intervalos em questão, conseguem projetar contribuições que fortalecem a justificativa do uso desses intervalos como elementos basilares na construção acórdica das estruturas e blocos sonoros do repertório moderno. Assim, em meus próprios termos, pretendi aqui relacionar alguns excertos da minha argumentação construída na pesquisa anterior sobre a questão intervalar em Almeida Prado.

1. Observa-se uma predominância do intervalo de $2^{\text {a }}$. menor e de seus correlativos (7a. maior - $8^{\text {a }}$. diminuta; $8^{\text {a }}$ aumentada - 9a. menor). Ainda que todos tenham recorrência equiparada, o intervalo de $2^{a}$. menor emerge como $\mathrm{o}$ extrato desta classe de quatro intervalos. [...] A espécie sonora gerada por esse intervalo é explorada nos planos verticais e horizontais; arrumados em nota contra nota que ao gerar o intervalo de segunda (menor) quer-se expandir o conceito de sobreposições e contraste por essa ocorrência intervalar. (Sant'Ana 2009 , p. 50, grifo nosso).

2. Se as estruturas acórdicas, em Almeida Prado, podem estar vinculadas a vários sistemas musicais - tonal, modal, atonal, serialismo livre etranstonalismo - tal vinculação ocorre por uma ordem de organizações intervalares que farão tais intervalos estar dentro de um sistema ou outro, ou na intersecção ou margem dos mesmos sistemas. Determinados tipos de intervalos são recorrentes, em cuja recursividade nota-se uma intenção e um planejamento no decurso da composição. Portanto essa ordem de padrões e recursividade define-se como a 'expressividade intervalar' num sentido ampliado do termo cunhado pelo próprio compositor. (Sant'Ana 2009, p. 48, grifo nosso).

3. O quadro de possibilidades de utilização intervalar envolve três intervalos. $\mathrm{O}$ primeiro deles considerado não somente a menor medida dos sistemas musicais baseados nos Doze Tons, mas de fato a segunda menor, torna-se o intervalo conceitual do compositor. Descendente do intervalo de segunda menor, os outros intervalos, o de sétima maior e o de nona menor fecham o quadro de relacionamento da segunda menor. O compositor toma estes intervalos e os coloca em projeção de valorização através da recorrência dos mesmos. [...] Forte e Straus colocam como categoria 1 [interval class] os intervalos de segunda menor, sétima maior e nona menor. A categorização de Forte e Straus coincide com a eleição dos mesmos intervalos por Almeida Prado nos Poesilúdios. Assim, Almeida Prado, apesar de conseguir por métodos ideológicos diferentes, tais intervalos (2a. menor e seus correlativos), os reconhece e atribui-lhes valor e importância de tensão máxima, ou o intervalo básico de maior tensão - a segunda menor [Persichetti, 1961, p.13]. (Sant'Ana 2009, p. 49, grifo nosso).

Abaixo, nas Exemplos 7 a 10, é demonstrada a relação de equivalência dos intervalos $2^{\mathrm{a}} \mathrm{m}, 7^{\mathrm{a}} \mathrm{M}$ e $9^{\mathrm{a}} \mathrm{m}$ como descrito na argumentação acima. 


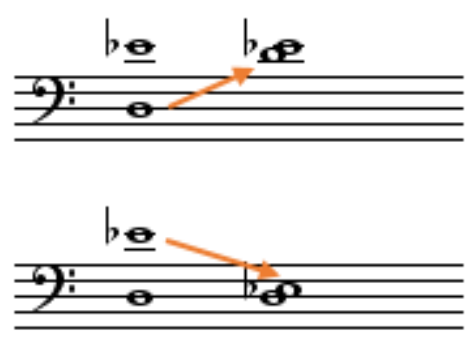

Exemplo 7 - 9a. menor e sua equivalência com a $2^{\text {a }}$. menor
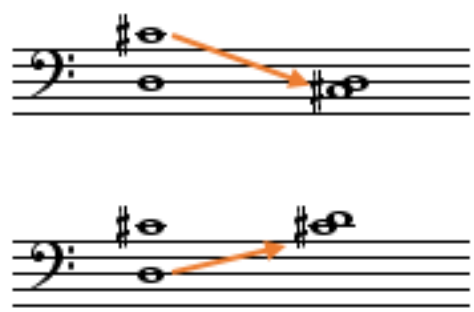

Exemplo 9 - 7a. maior e sua equivalência com a $2^{\text {a }}$. menor

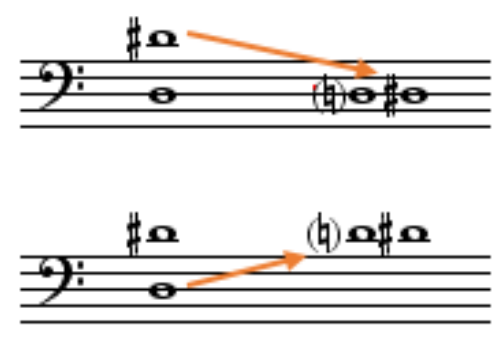

Exemplo 8 - 8a. aumentada e sua equivalência com a $2^{\mathrm{a}}$. menor

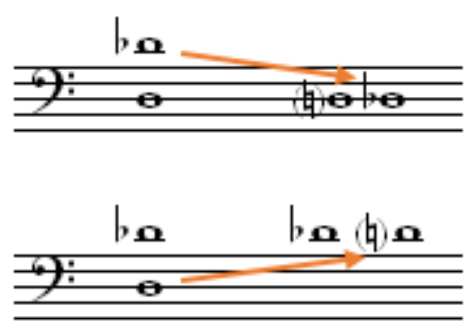

Exemplo 10 - 8a. diminuta e sua equivalência com a $2^{\text {a }}$. menor

Os intervalos de $2^{\mathrm{a}}$. menor ( $1^{\mathrm{a}}$. aumentada) e seus correlativos $-7^{\mathrm{a}}$. maior ( $8^{\text {a }}$ diminuta) e a 9a. menor ( $8^{a}$. aumentada) - têm também a função de estabelecer uma das faces da unidade textural e estrutural-tímbrica da composição pradiana. A recorrência intervalar específica sugere sua preferência por possibilidades existentes nessa classe intervalar. Esses intervalos podem se organizar em várias direcionalidades (horizontalidade, verticalidade e ou diagonalidade).

Reforçando a percepção de Almeida Prado quanto ao valor e potência desses intervalos, Flo Menezes (2002) escreveu a respeito da importância deles, definindo o fenômeno dos seus processos frequenciais sob o conceito da simultaneidade:

A emancipação das segundas menores do plano sequencial para o plano simultâneo fez com que um fator de proximidade melódica, essencialmente horizontal, fosse trazido para a verticalidade, perdendo, nesse processo, seu claro direcionamento melódico "sensível", de proximidade. Ao se perder a sensibilização melódica, ganha-se aí, em contrapartida, um equilíbrio ou estabilidade ambígua, bipolar, entre os dois componentes do intervalo. A 'dualidade de poder' presente na instabilidade de qualquer intervalo apolar de maneira antagônica comporta-se, aqui, como estável, equilibrada, exercendo um apoio acústico recíproco. Através da simultaneidade de ambos os componentes de uma segunda menor, tem-se, pois, a quebra de polarizaçãoúnica em face da dupla sensibilização simultânea presente no intervalo (em mais um processo

\section{MUSICA THEORICA}


típico de pantonalidade), pois que um som não mais se direciona melodicamente ao outro. Qual das duas frequências de uma nona menor, sétima maior ou segunda menor (e seus maiores desdobramentos pelas oitavas) se sobressai, se polariza, quando ambos os sons componentes do intervalo soam simultaneamente? Tal questão poderá encontrar resolução somente mediante os outros tantos fatores do contexto musical, entre os quais a presença de outras frequências que determinem a polaridade do aglomerado sonoro determinado, tendendo mais para uma nota do que para outra desses intervalos cromáticos verticalizados (Menezes 2002, p. 114).

A seguir sintetizo o que o autor tratou sobre a mudança de paradigma para o intervalo de segunda menor:

1) Sua emancipação se dá a partir da horizontalidade (sensível com preocupação melódica) à verticalidade (assimilação da estrutura em simultaneidade);

2) O advento das dissonâncias;

3) As duplas sensibilizações de meio-tom se incorporaram à alteração que a dominante sofreu no plano vertical (simultâneo);

Em resumo, a emancipação da segunda menor, bem como sua recorrente utilização, resulta "de seu comportamento estritamente horizontal à sua participação também nos aglomerados verticais, nos acordes", da "diacronicidade à sincronicidade" (Menezes 2002, p. 113). Almeida Prado que se autodefinia "um compositor muito tímbrico" (Prado e Moreira 2004, p. 76) pôde por essa declaração vincular sua produção composicional a um dos aspectos mais importantes do seu transtonalismo: o controle intervalar. Por compreender muito bem a dupla sensibilização da polaridade na 'emancipação da dissonância', foi que Almeida Prado pode aprofundar a pesquisa tímbrica na estruturação do material musical em simultaneidade. Foi enfatizando a seletividade intervalar que priorizava os harmônicos superiores e os inferiores da série harmônica, que Almeida Prado postulou sobre seu sistema transtonal dizendo que este "referese a uma mistura de serial, com atonal, com tonal. É o uso livre das ressonâncias, com alguns harmônicos usados de maneira consciente" (Prado e Moreira 2004, p. 75).

Se é ou não é plausível continuar a adotar o termo 'expressividade intervalar', ou este atual, a 'concepção intervalar' como 'intervalo característico', ao certo é que a questão da modelação intervalar em Almeida Prado é comprovadamente determinante. Ela pode ser reforçada teoricamente por vários conceitos-analíticos expostos, como: os intervalos polares e ou a polaridade ${ }^{8}$ de

8 "Em perfeita sintonia, com as concepções de Costère, ainda que aparentemente as desconhecendo, Pousseur afirma, noutro momento, que 'são, agora, nas noções de parentesco, de subordinação, de polaridade, de atração e repulsão... que se baseiam essencialmente as 
Costère (1954, 1963), a 'classe 1' da interval class de Forte (1973) e Straus (1990). Completando as proposições, acrescentei a polarização harmônica ${ }^{9}$ e a harmonia de simultaneidade de Pousseur (Pousseur 2009), (Menezes 2002, 2009).

Em síntese, e reconhecendo a importância que Almeida Prado dá ao problema do intervalo, pode-se apontar para o que Massimiliano Locanto (2009) disse em seu texto Composition with Intervals: Intervall Syntax and Serial Technique in Late Stravinsky: "embora todos estes compositores tratem o componente intervalar de maneiras diferentes, tornou-se para eles o aspecto fundamental de uma técnica motívica". Uma base, "um número restrito de figurações intervalares que servem a uma função unificadora dentro de uma obra musical" (Locanto 2009, p. 221). Compreenda-se essa técnica motívica como uma apropriação generalizada do elemento intervalar que será largamente utilizado diacrônica e sincronicamente.

Se Locanto falou de Stravinsky, incluindo Schoenberg, Webern e Berg como preocupados com as possibilidades do intervalo, podemos também inserir Almeida Prado, como outro compositor a privilegiar em alta conta o controle e o cuidado pontual quanto à estruturação intervalar.

\section{Sonata № 3 (1984) para piano de Almeida Prado: Alguns Exemplos de 'Intervalos Característicos'}

\subsection{Clusters: segundas menores - itens importantes nessa estrutura acórdica (mov. I, c. 1-2)}

Ocorrem três clusters no primeiro movimento dessa sonata. Como estrutura acórdica, esse material tem sua execução diferenciada, deve ser realizada com o auxílio do antebraço, segundo recomendação do compositor, em partitura confeccionada por Nadai (2007). Ocorrem três estruturas de cluster nesse movimento (c. 1-2; c. 12-13; c. 25-26). Todos eles possuem alguma associação com o intervalo de segunda menor. Observe-se que no segundo cluster, não ocorre o 'intervalo característico' devido às pentatônicas realizadas

propriedades proporcionais [leia-se: harmônicas] dos intervalos e dos grupos de intervalos" (Pousseur 1968, p. 113 apud Menezes 2005, p. 301).

${ }^{9}$ Em Pousseur (2009, p. 195), Menezes (2009) faz uma nota na tradução brasileira para o Apoteose de Rameau, em que ele comenta que "constata-se que a pesquisa de Pousseur, que se mostra muito convergente com as de Edmond Costère (às quais já nos referimos), desenvolveu-se de forma totalmente independente do teórico francês. Num certo sentido, a intuição paralela de ambos apenas reforça esse 'dado natural' em que consisteo que poderíamos designar por fenômeno da polarização harmônica”. 
em teclas pretas, mas, ainda assim ocorre no baixo a segunda menor entre Ré0 e Mib0. Dois aspectos podem ser observados no primeiro e terceiro cluster. São eles:

1) O cluster é uma estrutura acórdica com intervalos de segundas ( $\mathrm{M} \mathrm{e} \mathrm{m}$ ), considerando as segundas menores como pertencentes ao mecanismo do 'intervalo característico'.

2) Outro aspecto, é o fato dessa estrutura ser auxiliada pela pedalização livre (pedal direito no piano) que serve a objetivos acústicos do transtonalismo, cumprindo um procedimento comum na execução musical quando utiliza esse sistema musical (a pedalização como princípio de ressonância).

O primeiro cluster, na abertura da peça, tem o desenho mostrado no Exemplo 11:

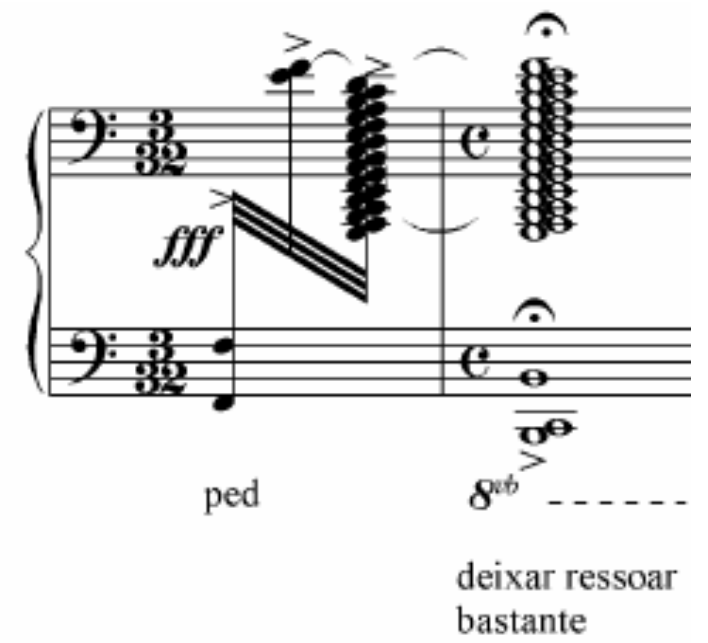

Exemplo 11 - Cluster: componentes de segundas maiores e menores (conf. Nadai 2007)

O segundo cluster não contém o 'intervalo característico', entretanto, como detalhe, possui no baixo uma ocorrência de segunda menor: 


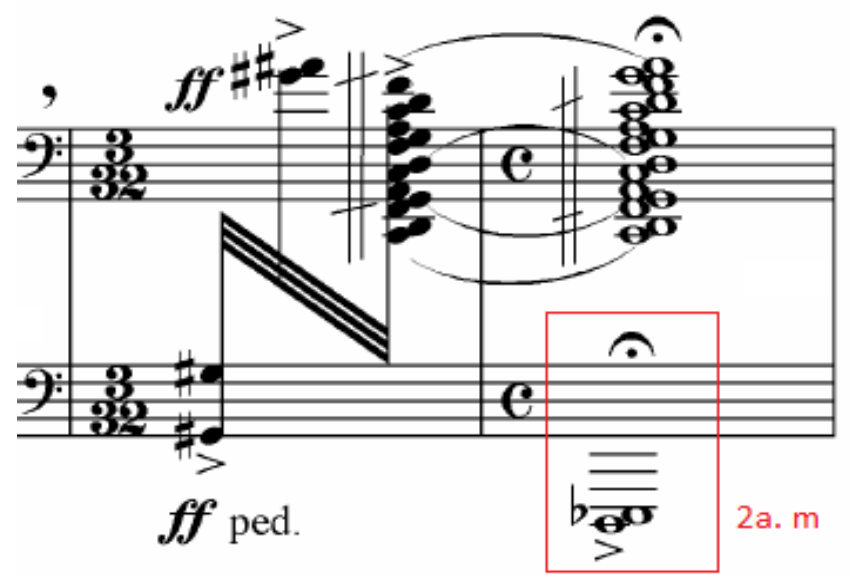

Exemplo 12 - 'Intervalo característico' no baixo (conf. Nadai 2007)

E ainda o terceiro cluster, com a utilização de 'intervalo característico':

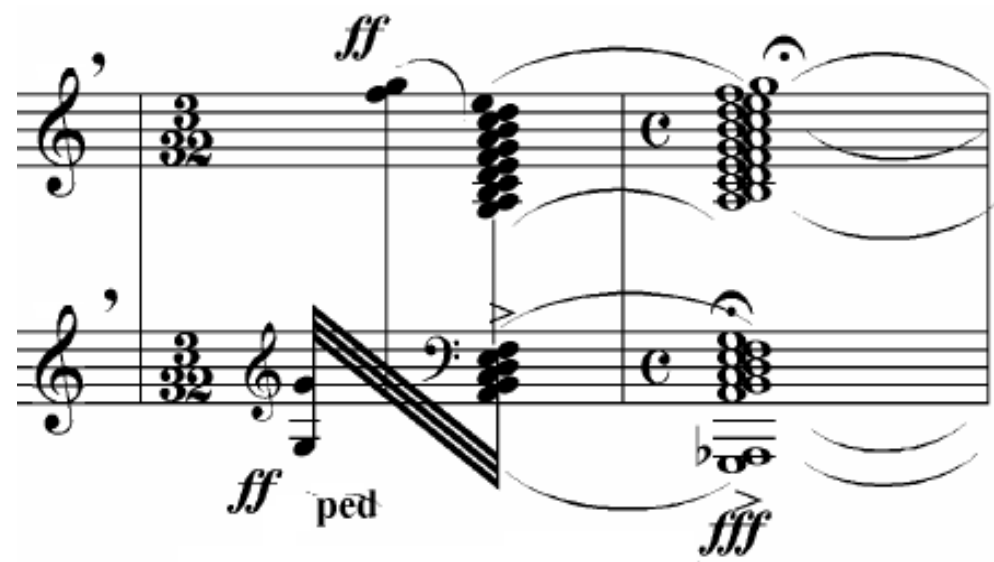

Exemplo 13 - Cluster: componentes de segundas maiores e menores (conf. Nadai 2007)

\section{2. 'Intervalo característico' como acompanhamento (mov. I, c. 3-7)}

A segunda menor, em disposição sincrônica, segue com a proposta de um ostinato. Uma ideia de camada. Almeida Prado tem uma predileção por essa arrumação, construindo camadas, como estratificações de materiais, ampliando a ideia e manutenção das sobreposições com objetivo de contraste.

A camada, como que um acompanhamento para um material melódico, é estabelecida pela repetição ostensiva do intervalo de segunda menor em uma mesma altura. O 'intervalo característico' passa a ocupar o lugar da entidade acordal com função de acompanhamento harmônico. Substitui a estrutura acórdica como elemento acompanhante da melodia. 


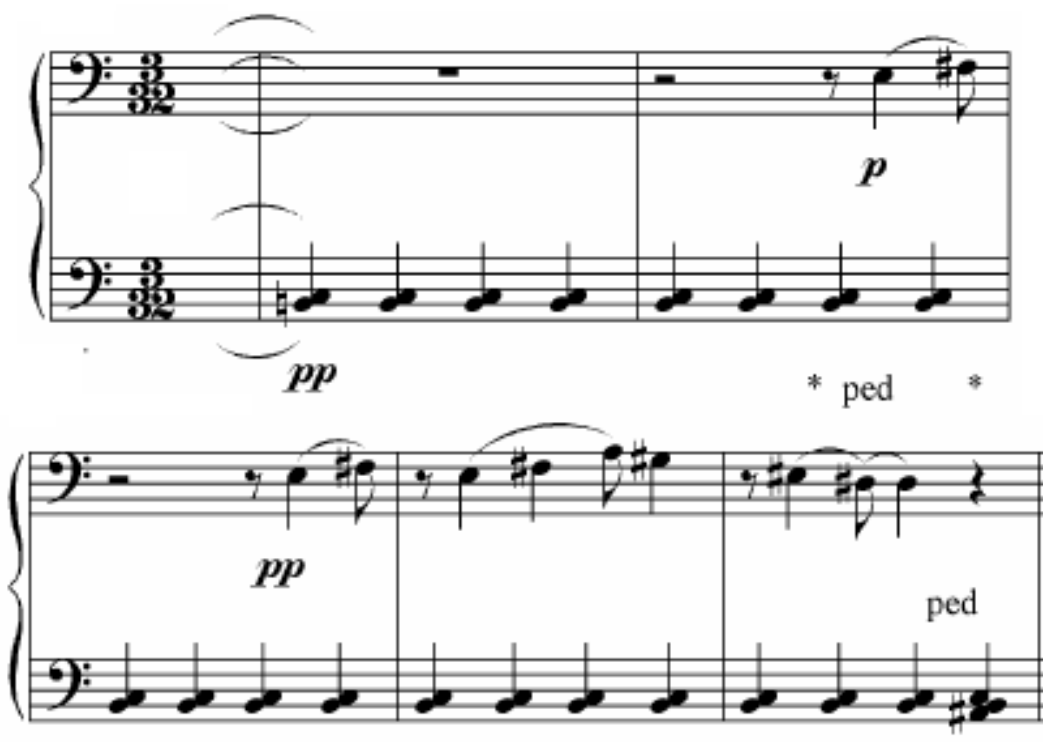

Exemplo 14 - 'Intervalo característico' como ideia de acompanhamento (ostinato)

\section{3. 'Intervalo característico' por acumulação (mov. I, c. 7-8 e 19-20)}

No próximo exemplo, Almeida Prado utiliza um mecanismo de acumulação intervalar por segunda menor. A partir da referência anterior do ostinato que agrega sincronicamente o Si1 e o Do2, ocorre um empilhamento que vai desse intervalo de segunda menor ao esquema cumulativo em direção à tessitura mais grave. Uma técnica de empilhamento invertido. $\mathrm{O}$ intervalo de segunda menor vai sendo vez após vez adicionado, deixando a estrutura acórdica em situação de novidade constante. Um processo cumulativo de intervalos, uma ideia somatória.

Uma construção por meio de 'empilhamento intervalar', faz rapidamente ocorrer uma transição de uma estrutura acórdica qualquer para uma estrutura em cluster.

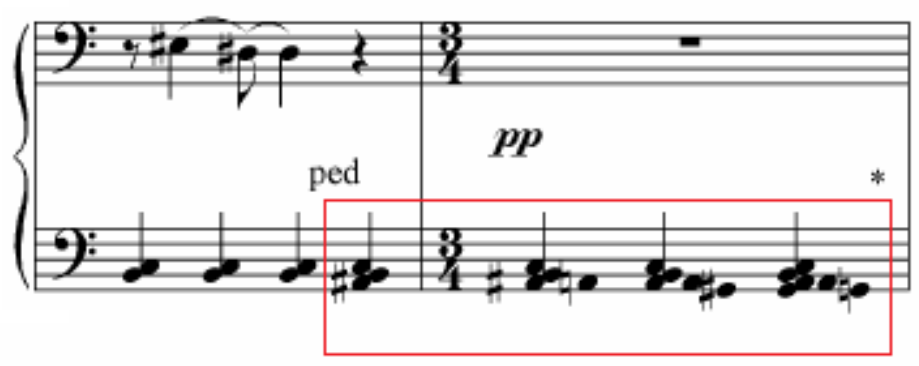

Exemplo 15 - Processo cumulativo de segundas menores: uso dos materiais por meio de 'intervalo característico' 
Nos compassos 19 e 20 do Movimento I, a construção através de acumulação intervalar ocorre de uma maneira mais ampliada (repetição do processo dos compassos 33 a 35).

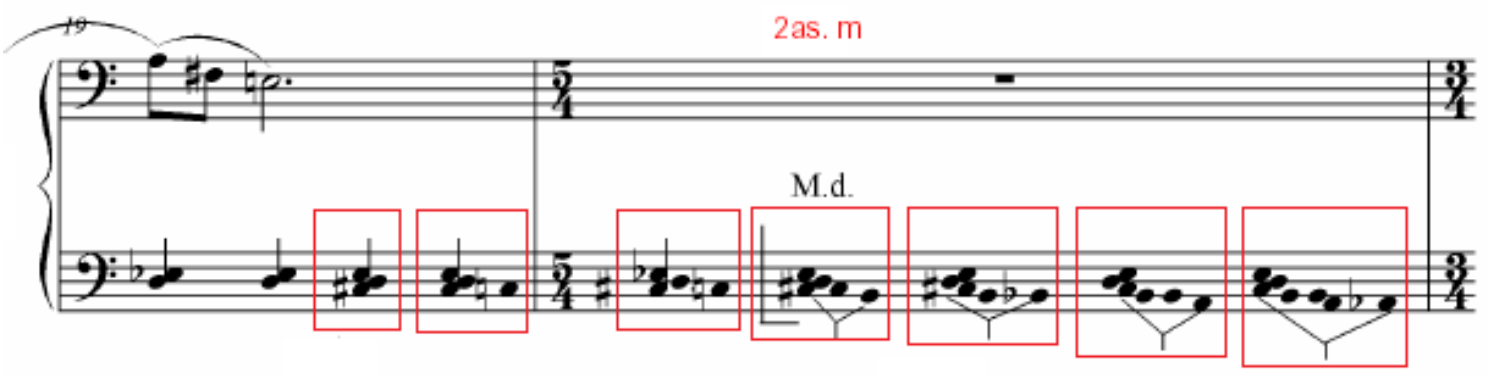

Exemplo 16 - Acumulação contínua do 'intervalo característico' em direção ao grave

\subsection{Tematização por 'intervalo característico' (mov. I, c. 9-10)}

Intencionalmente o compositor estabelece uma 'tematização' 1011 do tipo intervalar fazendo a reiteração da segunda menor. A ocorrência intensiva do intervalo é mantida desde o primeiro movimento da peça. Já em terreno do segundo movimento, o intervalo ainda continua sendo material almejado para o seguimento estrutural. Há de se observar que as correlações de direção, nesse trecho, são unicamente de horizontalidade. O seguimento estabelecido de ordem melódica pode ser tocado com uma única mão (esquerda ou direita, como se queira), com caráter de um trinado ampliado e subvertido e que depois fatualmente, na nota Ré4, exerce a pontuação da frase (o trinado real ocorre com incidência da segunda menor entre o Ré4 e Mib4). Interessantemente, a mesma pontuação serve ao papel de uma ponte que liga ao próximo material. Portanto, a segunda menor segue com desenvoltura na construção, e comprovadamente a predominância do tipo intervalar é facilmente identificada no exemplo mostrado no Exemplo 17.

10 “Não há tematização sem desdobramento, não há refrão sem segunda partee não há gradação de alturas sem a intervenção dos saltos intervalares" (Tatit 1997, p. 97).

11 Tematização como repetição, como padrão, como organização reiterada, como algum tipo de norma ou alguma razão. 


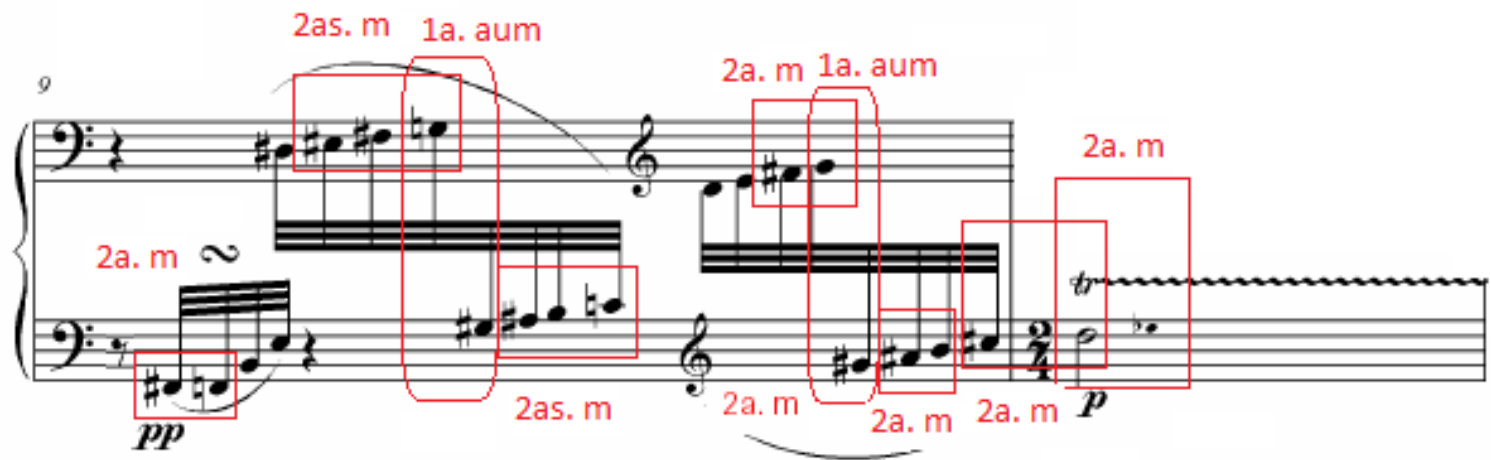

Exemplo 17 - Predominância de um tipo intervalar: a segunda menor (ou primeira aumentada) - uma ordem direcional horizontal (ocorrência de um tipo de 'intervalo característico').

\subsection{Relações de direcionalidade diagonal (mov. II, c. 6-7)}

As direcionalidades são ordens de organização intrínseca às modelizações intervalares e tem importância necessária na estruturação musical que o compositor desenvolve. Há de se ter uma certa dose de atenção à direção diagonal. Geralmente as direcionalidades horizontais e verticais são mais prontamente observadas. Portanto, na diagonalidade pode residir sutilezas e relações inesperadas. "A música pode então ser definida como direcionalida des conscientemente elaboradas" (Menezes 2013, p. 74).

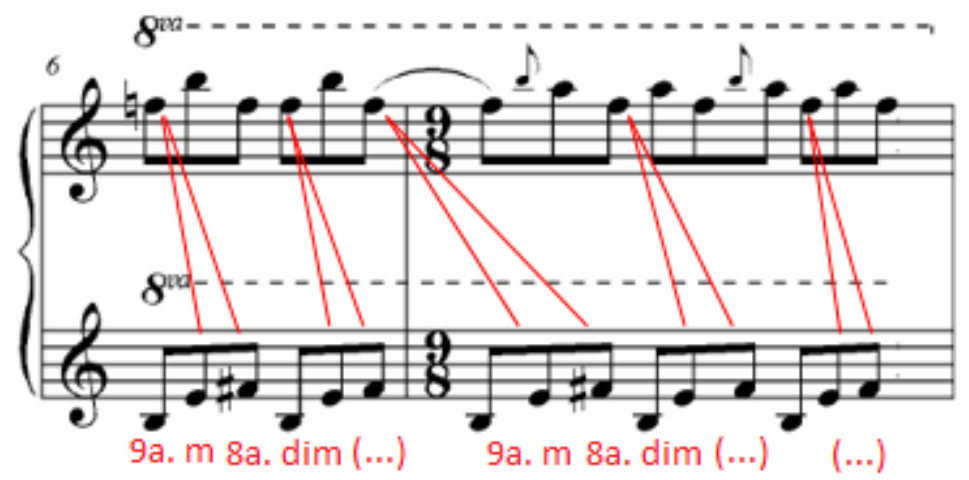

Exemplo 18 - Relação diagonal de 'intervalos característicos' de 9a m e 8ª dim

O exemplo acima, além de ser capaz de demonstrar a direção em diagonalidade, ao mesmo tempo pode apontar para a 'padronização intervalar', o que similarmente se chamou de 'tematização do intervalo'. No caso do exemplo do Exemplo 18, percebe-se que a ocorrência dos intervalos se dá na ordem sucessiva de nona menor e oitava diminuta (equivalente à sétima maior). 


\subsection{Aceleração rítmica por 'intervalo característico' (mov. II, c. 27-31)}

Dos compassos 27 até ao 31 do Movimento II, ocorre uma intensificação mais acentuada do uso do 'intervalo característico' de segunda menor. Nesse trecho identifica-se também uma aceleração rítmica, tendo no compasso 27 indícios dessa aceleração por mudança de figura. A colcheia usual se transforma em semicolcheia na linha inferior.

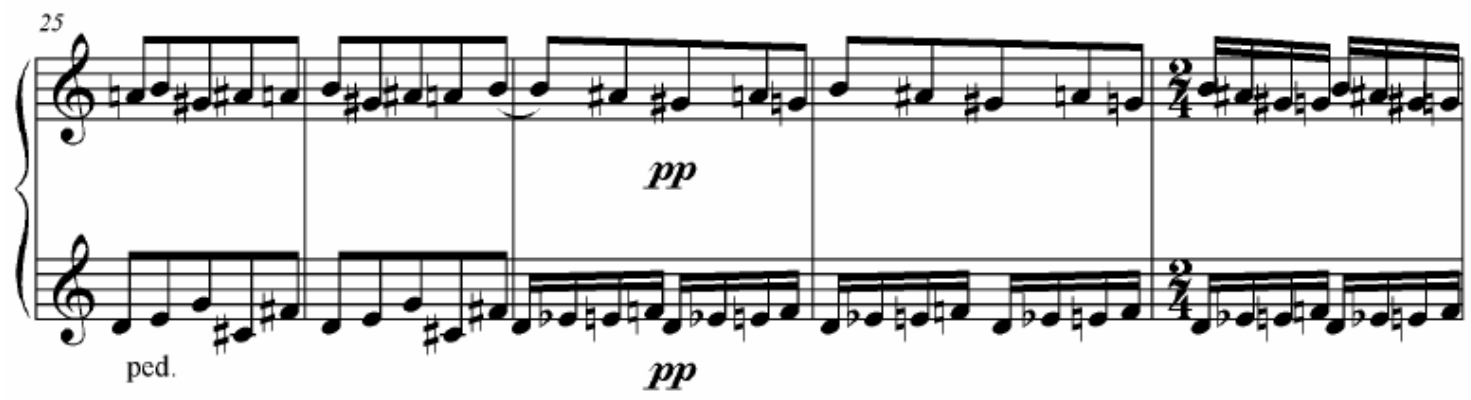

Exemplo 19 - Semicolcheias no c. 27 indicando aceleração rítmica

No Exemplo 20 (c. 30-31), os dois compassos apresentam nova inserção de velocidade. Esse efeito se dá pela substituição da figura de semicolcheia pela fusa. As segundas menores continuam predominantes na horizontalidade praticando o mesmo movimento contrário entre a linha inferior e a linha superior (iniciado no c. 27 seguindo até ao c. 31). Sincronicamente, esse movimento contrário das linhas gerais de intervalos genéricos do tonalismo culmina sempre com uma segunda maior na última fusa. No compasso 31, além da manutenção da horizontalidade das segundas menores, o compositor reforça sincronicamente com uma nova inflexão de segundas menores versus segundas maiores sobrepostas em todos os conjuntos de fusas da célula rítmica desse compasso.

Toda disposição envolvendo a intensificação do referencial do intervalo de segunda menor busca estabelecer um contraponto cromático adensando o som como uma ideia de batimentos ${ }^{12}$ de uma onda sonora. Essa intensificação das segundas em conjunto com a aceleração rítmica produz um aspecto de 'radição sonora', um procedimento que privilegia "certas dissonâncias para realçar batimentos [...] e difusões sonoras" (Ferraz 2006, p. 16).

\footnotetext{
${ }^{12}$ Batimento (ing. beat; it. battimento; fr. battement; al. Schwebung): choque de frequências entre sons muito próximos, mas não idênticos, que proporcionam a sensação de pulsação por oscilarem de forma constante" (Dourado 2004, p. 47).
} 


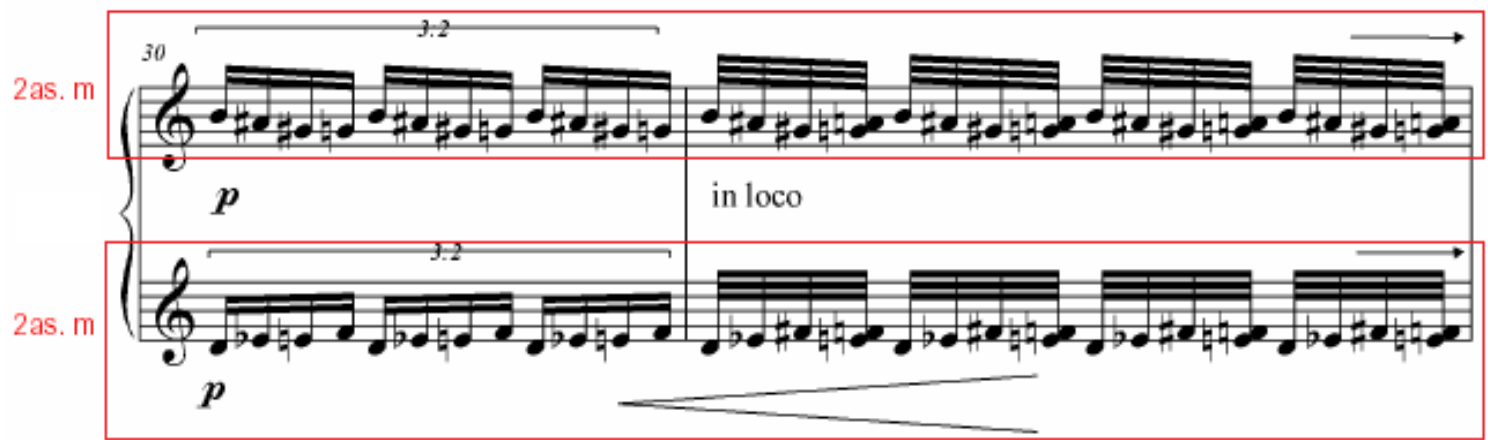

Exemplo 20 - Contraponto de segundas menores: intensificação e clímax sonoro

\subsection{Modelo motívico com 'intervalo característico' na estrutura rítmica (mov. II, c. 71-73 e c.84)}

O fragmento abaixo revela uma similaridade rítmica-intervalar com o conceito da tematização intervalar. Pode-se classificar como um modelo recorrente de um formato motívico por meio de segunda menor. Esse modelo carrega a padronização rítmica em conjunto com a já observada tematização intervalar (nesse caso, a repetição do 'intervalo característico' na primeira nota do conjunto das quatro semicolcheias).

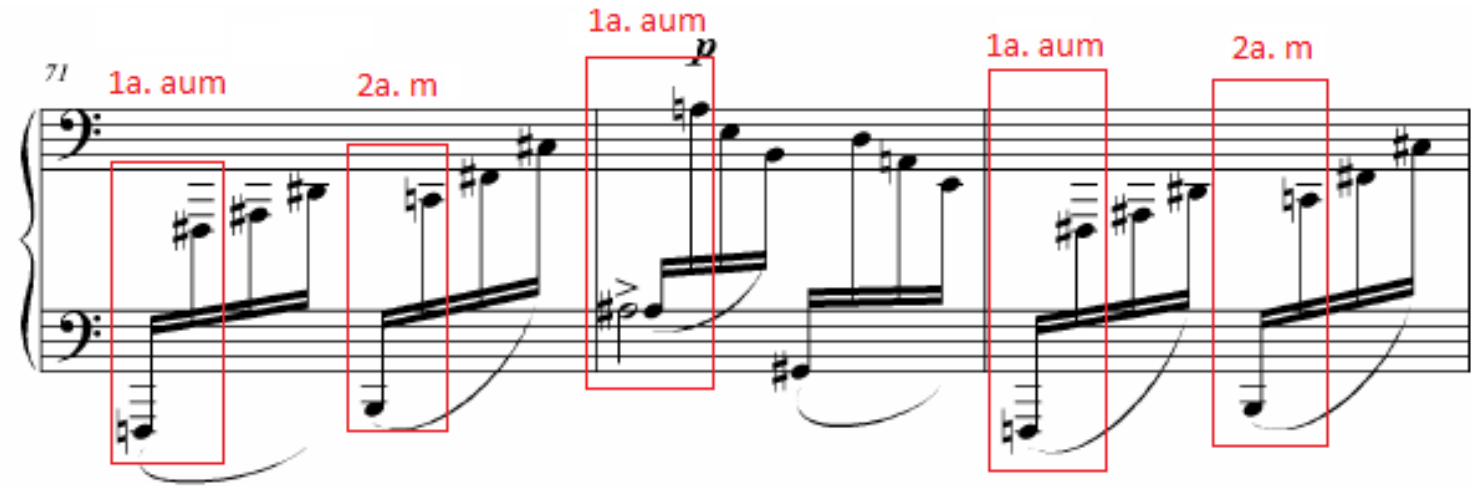

Exemplo 21 - Modelização rítmica-intervalar com base no 'intervalo característico' Ocorrem alguns intervalos de primeira aumentada (semelhantes à segunda menor)

Outro caso, mostrado no Exemplo 22, com o mesmo desenho estrutural na forma rítmica de quatro semicolcheias, faz ocorrer uma esquematização onde o compositor coloca a primeira nota mais grave como base para se estabelecer a relação de 'intervalo(s) característico(s)' nas $2^{\text {as }}$ e $4^{\text {as }}$ semicolcheias: segunda menor e oitava diminuta. Uma 'tematização intervalar' com relação de diagonalidade está presente no compasso 84 do Movimento II (ocorre igualmente nos compassos anteriores 80 e 82). 


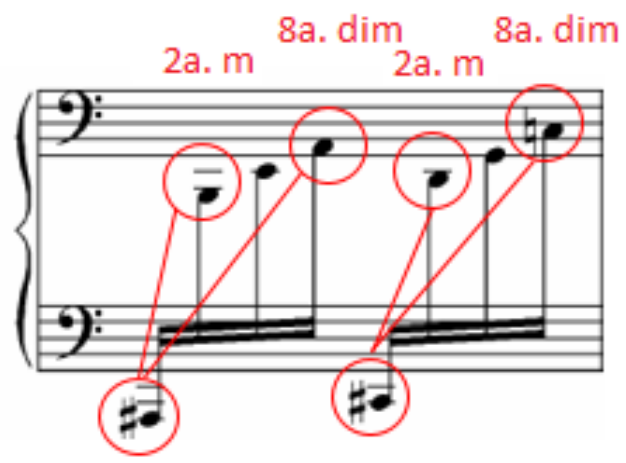

Exemplo 22 - Padronização da ocorrência do(s) 'intervalo(s) característico(s)'

\subsection{Relação intervalar e diagonalidade (mov. II, c. 74)}

No exemplo mostrado no Exemplo 23 há novamente uma ocorrência de 'intervalos(s) característico(s)' em diagonalidade pela 'tematização intervalar'. Entretanto, nesse caso são usados dois tipos de intervalos (nona menor e segunda menor), contando com a enarmonia entre a nona menor e a oitava aumentada (ou vice-versa). A enarmonia traz uma sutileza e dubiedade para a interpretação a partir do registro grafado do intervalo.

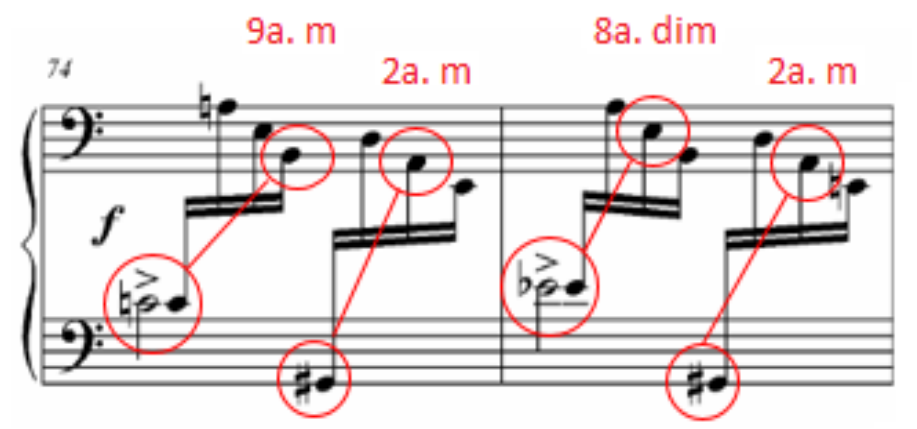

Exemplo 23 - A organização intervalar em diagonalidade

\subsection{Padronização do 'intervalo característico' em um modelo rítmico (mov. II, c. 94)}

Almeida Prado, tentando expandir o processo intervalar, continua com a lógica do 'intervalo característico' como elemento participante e gerador de outras possíveis organizações recorrentes (a 'temática do material'). No trecho mostrado no Exemplo 24, em termos de figuras rítmicas ocorre uma horizontalização da questão. Em contrapartida, esse material pode ser pensado também como uma opção que parte do grave para o agudo, seguindo uma ascendência sempre constante nesse compasso. A relação ascendente busca 
intercalar cada tercina (três colcheias na tercina: $1^{\text {a }}$ figura da tercina: som grave;

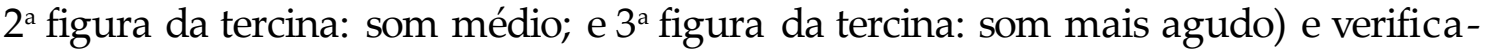
se aí uma direcionalidade diagonal ascendente. São nas figuras extremas da tercina (grave: $1^{\text {a }}$. colcheia da tercina; e a aguda: $3^{a}$. colcheia da tercina) que ocorre a relação do 'intervalo característico'. O exemplo do Exemplo 24, que demonstra essa disposição, foi retirado do compasso 94 do Movimento II.

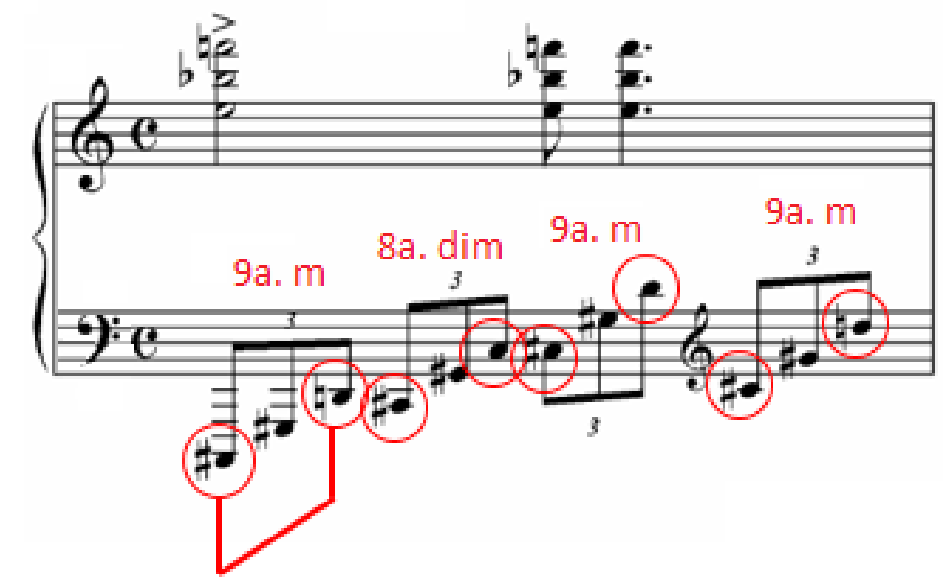

Exemplo 24 - Ocorrência do 'intervalo característico' em modelo rítmico: a tercina

\subsection{Sobreposição intervalar tematizada (mov. II, c. 134-136)}

Esse exemplo é baseado na verticalidade da 'concepção intervalar', seguindo uma ideia de variar os materiais, buscando novas soluções dentro do desenvolvimento composicional, Almeida Prado propõe a 'sobreposição da estrutura intervalar'. Ele desenvolve conceitualmente algumas possibilidades dentro do eixo da oitava. Parece ser, nessa passagem, um esforço para algumas variantes contrastantes à força da polaridade da oitava. As possibilidades são desenvolvidas em torno dessa distância intervalar básica: a oitava justa. Sendo assim, a sétima maior, como meio-tom menor que uma oitava justa, da mesma maneira, a oitava aumentada como meio-tom maior que uma oitava justa. $\mathrm{O}$ modelo estrutural intervalar é baseado nessa formação vertical que explora as possibilidades nas cercanias da oitava justa: acrescentando intervalos sobrepostos predominantes de segunda menor e de sétima maior ao mesmo tempo. 


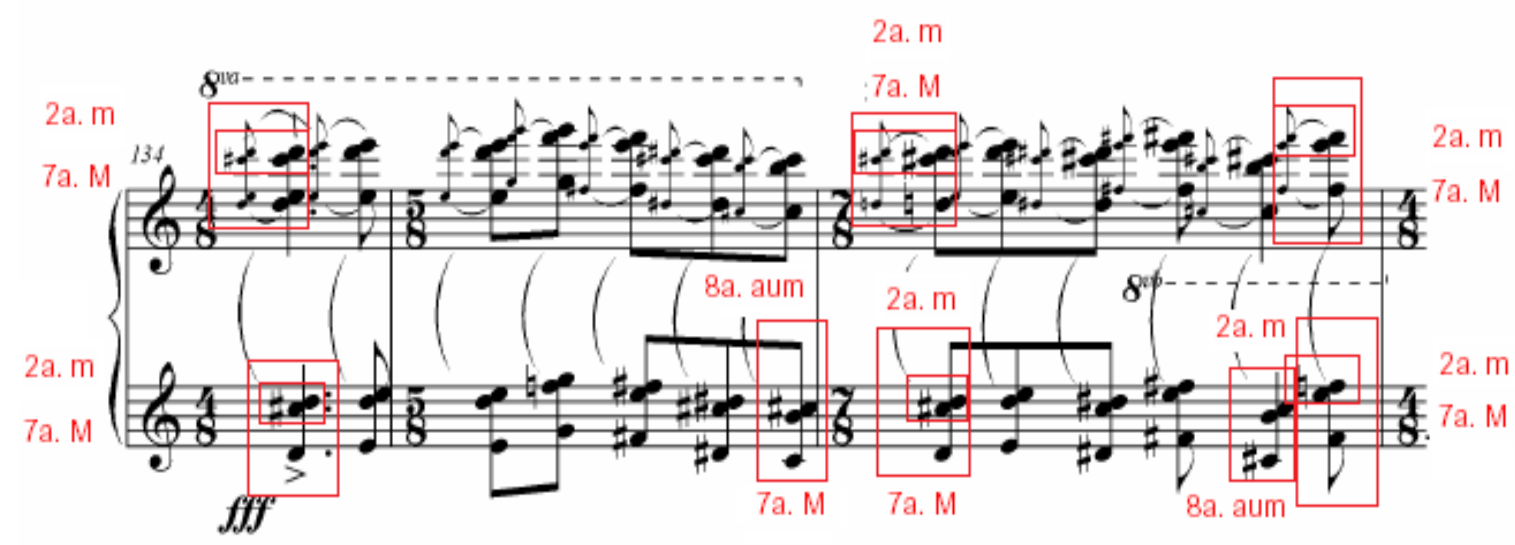

Exemplo 25 - Partindo da oitava ao 'intervalo característico': direcionalidade vertical

\subsection{Modelo motívico interseccionado pelo 'intervalo característico' (mov. II, c. 141-143)}

Esse modelo rítmico que se desenvolve nos compassos 141 até ao 143, possui um primeiro termo na cabeça do motivo de duas tercinas, mais duas colcheias, tendo as notas Lá\#0, Fá\#1, Do2, Lá1, Si1, Lá\#1 e Si1. Observe-se que o 'intervalo característico' de segunda menor ocorre três vezes (segundo termo), como uma divisão entre o primeiro e o último termo. $\mathrm{O}$ terceiro termo do material motívico é sempre aumentado por somatória de um grupo de duas ou mais colcheias. A cada nova aparição do motivo e dos novos elementos, o terceiro termo vai se alongando propiciando o aumento do tamanho integral do motivo. Assim, o motivo se alarga, vez após vez, pela sua própria transformação e reiteração tentando alcançar status de tema.

Do compasso 141 ao 143 , cada compasso tem um padrão de medida de pulsos em colcheias (8): 8 por 8 ; 11 por 8 e 13 por 8 . 

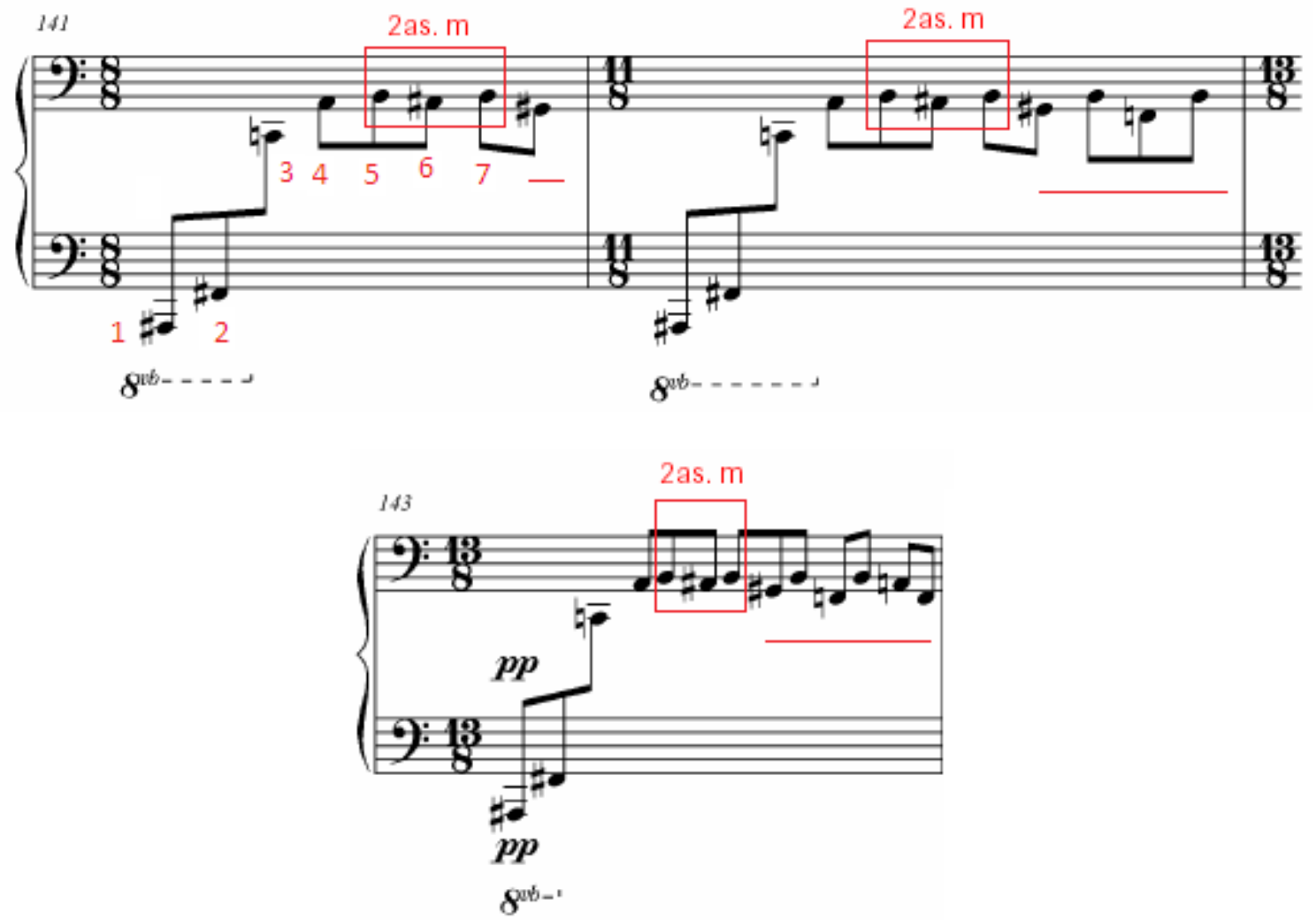

Exemplo 26 - Modelo intervalar-rítmico por aumentação, separado por 'intervalo característico'

\subsection{Intensificação dos intervalos ascendentes de segundas menores: com sobreposição de quartas justas (mov. II, c. 147-150)}

Um exemplo de intensificação e saturação das segundas menores e suas possibilidades combinatórias com outros materiais intervalares é mostrada no Exemplo 27. Em termos poéticos, o compositor trata de dar manutenção ao artifício da 'tematização intervalar'. Observando a partitura completa, o jogo quartal já se inicia no compasso 146. Acontece a inclusão da primeira sobreposição no compasso 148 , tendo a intensificação maior desse processo no compasso 150, onde ocorrem as sobreposições quartais que se estenderão a posteriori nos compassos 151 ao 154. Observe-se no Exemplo 27 os compassos 147 ao 150: 


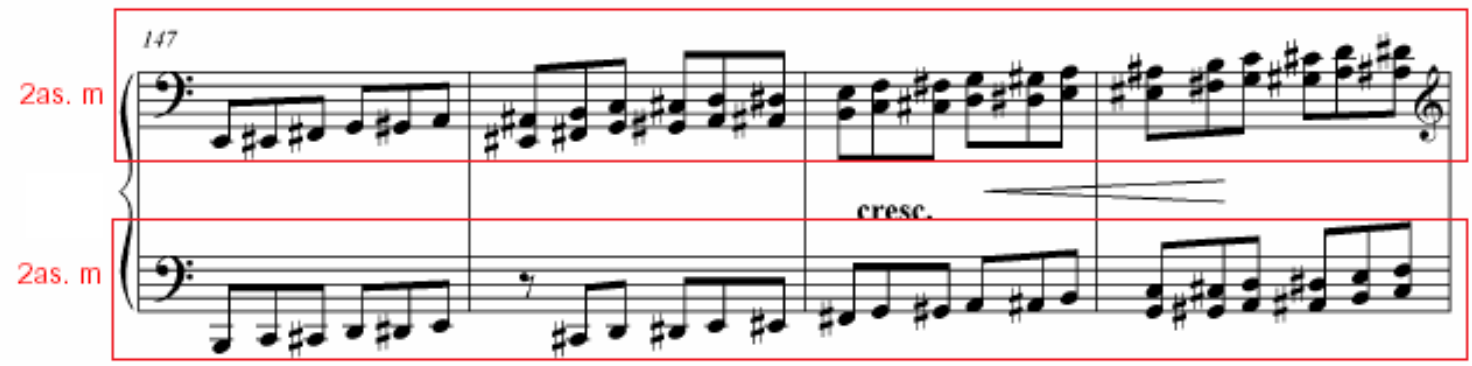

Exemplo 27 - Sobreposição quartais em horizontalidade das segundas menores

\subsection{Continuidade da intensificação da sobreposição e superposição intervalar de quartas = acorde quartal sobre acorde quartal (mov. II, c. 155-157)}

Na progressão dos acordes quartais ocorrem o 'intervalo característico' de sétima maior. A estrutura segue em direção ascendente que caminha para um clímax no compasso 157, com outra estrutura acórdica com o 'intervalo característico' de oitava diminuta, o qual é similar à sétima maior.

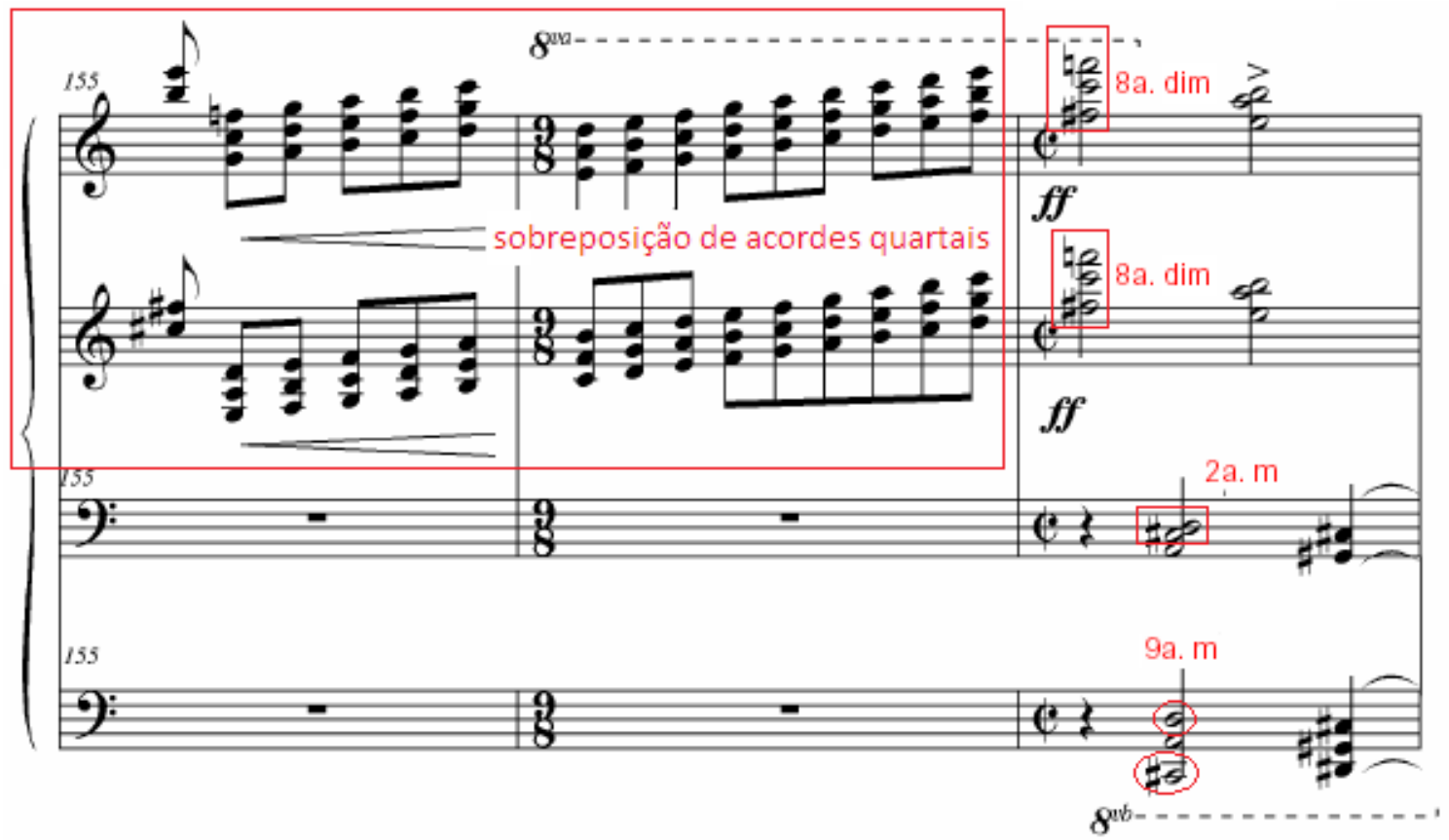

Exemplo 28 - Acordes quartais com clímax utilizando 'intervalo(s) característico(s)' 


\subsection{Relação espelhada de 'intervalo característico' (mov. II, c. 172-173)}

Apresenta-se aqui um caso inusitado da combinação intervalar ainda não ocorrida nesta obra: um trato espelhado das segundas menores, sendo esse procedimento uma espécie de alusão semantizada ao serialismo. Em alguns aspectos, essa ordem de alusão ao procedimento serial, em partes, faz lembrar o vínculo serial-tonal da poética plural ${ }^{13}$ de Berg.

Entretanto, o serialismo de Almeida Prado é anunciadamente livre. A própria menção do espelhamento, mesmo que de forma transformada e semantizada, torna-se uma concepção continuada a partir do sistema serial. Entendendo que a forma retrógrada $(\mathrm{RO})$ e a forma inversa do original $(\mathrm{IO})$, no serialismo dodecafônico, são ideias pertencentes à organização direcional por espelhamento, ainda assim convém lembrar que o procedimento espelhado é largamente utilizado muito anteriormente, no período Barroco, especialmente em J. S. Bach.

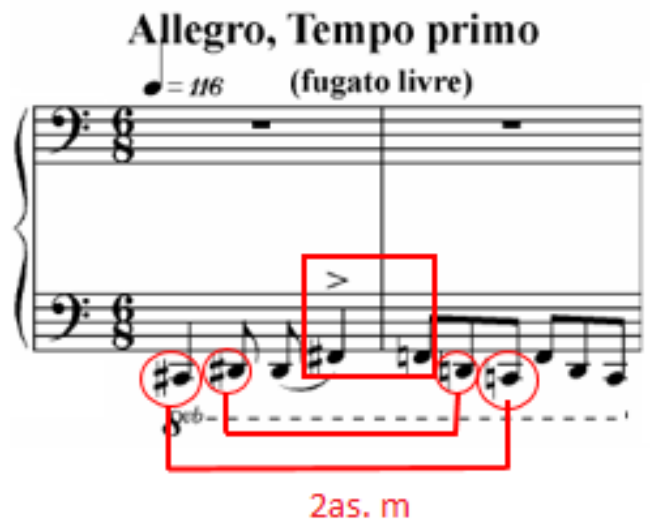

Exemplo 29 - Espelhamento de relações pelo 'intervalo característico' de segunda menor

Levando-se em conta os dados analíticos, percebe-se que o compositor transita inicialmente a partir de um sistema tonal que facilmente se desdobra em elementos da música atonal e serial. Nessas condições, é perfeitamente plausível compreender tais artifícios que declaradamente fazem com que Almeida Prado transite entre o tonal e o atonal. Tal compreensão, pode ser ajustada à perspectiva e aos propósitos do 'espaço entre' ('entre sistemas').

13 "Alban Berg acabou descobrindo seu próprio caminho através de uma expansão complexa e pouco ortodoxa do método, trabalhando com séries diferentes, mas correlatas e combinando operações seriais à rica harmonia tonal que nunca estivera totalmente ausente de sua música" (Kozu 2000, p. 6). 


\section{Considerações Finais}

Percebeu-se que há uma equivalência da minha proposição conceitual do 'intervalo característico' aos diversos conceitos teóricos arrolados anteriormente. $\mathrm{O}(\mathrm{s})$ 'intervalo(s) característico(s)' compõem um processo efetivo, produzindo na estrutura composicional de Almeida Prado uma malha condutora que lhe dá um caráter orgânico. Essa 'concepção intervalar', tanto materializa a base de uma estrutura condutora de organicidade, como também abre caminhos com grande índice de inovação e possibilidades. No sentido das possibilidades, seu gesto poético se apropria de novas contemplações sonoras como à semelhança de um pintor que vai materializando suas ideias, enveredando por visões inesperadas, planejamentos e moldagens inéditas nos conjuntos e expressões sonoras. Essa conjectura teórica é passível de ser aplicada nesse terreno novo, virgem e inesgotável das combinações intervalares de segunda menor, sétima maior e nona menor, somadas às outras possibilidades oriundas das estruturas acórdicas mais ou menos pertencentes a outros sistemas musicais.

Os intervalos específicos estudados para se compreender a composição de Almeida Prado nas fases pós-ruptura, precisaram ser entendidos como estruturas que foram reforçadas por sobreposição a outros intervalos gerais aqueles frequentemente representados nos sete primeiros harmônicos da série harmônica. A projeção do(s) 'intervalo(s) característico(s)' correlacionados aos outros intervalos genéricos é uma espécie de construção microscópica da poética de contraste. Há uma expansão dessa poética que vai das menores estruturas para as grandes estruturas na organização de sua obra nas fases pós-ruptura. Elas são perfiladas do mínimo ao máximo. Os planos micro e macro seguem esse conceito. As sobreposições contrastantes se tocam e se complementam. O intervalo consonante reforça o intervalo dissonante perfazendo as estruturas contrastadamente. A estrutura atonal do(s) 'intervalo(s) característico(s)', como índice de maior dissonância potencial intervalar no total cromático, é contrastada e outra vez potencializada no interior e contexto dos intervalos genéricos ligados ao background tonal. Contrariando as normas para as considerações finais, eu diria, citando Pousseur, que na composição de Almeida Prado ficam patentes a "simetria e assimetria, determinação e indeterminação, igualdade e desigualda de [...], e estes atributos neste compositor, [...] não são, pois, princípios simplesmen te contraditórios que se excluem entre si de maneira absoluta, mas sim propriedades complementares, que se condicionam mutuamente e que precisam uma da outra" (Pousseur 2009, p. 103). 


\section{Referências}

1. Almeida Prado, José Antonio Rezende de. 2001. Encontros com Almeida Prado: Entrevista compilada por Valéria Peixoto. Rio de Janeiro: Academia Brasileira de Música.

2. 1986. Cartas Celestes - Uma Uranografia Sonora Geradora de Novos Sons. Tese (Doutorado em Música). Campinas: UNICAMP.

3. 1986. Modulações da memória: (um memorial). Memorial para Doutorado em Música. Campinas: UNICAMP.

4. Bent, Ian D. e Pople, Anthony. 2001. Analysis. In: The New Grove Online. Londres: Macmillan.

5. Bitondi, Matheus G. 2006. A estruturação melódica em quatro peças contemporâneas. Dissertação (Mestrado em Música). São Paulo: UNESP.

6. Bittencourt, Marcus A. 1999. Um modelo computacional das teorias de Edmond Costère e da Teoria de Conjuntos implementado em uma ferramenta analítica em PHP. 7.o Simpósio Brasileiro de Computação Musical. Disponível em: http://www.music.columbia.edu/ alessi/wiki/lib/exe/fetch.php?media=pdfs:Bitt encourt_SBCM2007.pdf.

7. Boulanger, Nadia. 1926. Lecture on Modern Music. Houston: The Rice Institute Pamphlet.

8. Coelho de Souza, Rodolfo. 2009. Uma introdução às teorias analíticas da música atonal. Pesquisa em música no Brasil: métodos, domínios, perspectivas. Rogério Budasz (org.). Goiânia: ANPPOM.

9. Costère, Edmond. 1954. Lois et styles des harmonies musicales. Paris: Presses Universitaires de France.

10. Costère, Edmond. 1962. Mort ou Transfigurations de l'Harmonie. Paris: Presses Universitaires de France.

11. Dourado, Henrique A. 2004. Dicionário de termos e expressões da música. São Paulo: Editora 34. 
12. Ferraz, Silvio. 2002. Varèse: a composição por imagens sonoras. Musicahoje, Belo Horizonte: UFMG. Disponível em: http://sferraz.mus.br/varese.pdf

13. Forte, Allen. 1973. The structure of atonal music. New Haven: Yale UP.

14. Kozu, Fernando. 2000. O serialismo dodecafônico. Ciclo de Palestras: Aspectos da Música do Século XX. NMC - Núcleo de Música Contemporânea CEC/CECA/UEL, Londrina.

15. Lima, Paulo C. 2011. Caminhos da Análise II. Disponível em: https://paulocostalima.wordpress.com/tag/caminhos-da-analise-musical-ii Acesso em: 12 jun. 2013.

16. Locanto, Massimiliano. 2009. 'Composition with Intervals': Intervallic Syntax and Serial Technique in Late Stravinsky. In: Music Analysis, v. 28, n. 2-3, p. 221266.

17. Menezes, Flo. 2002. Apoteose de Schoenberg: Tratado sobre as Entidades Harmônicas. 2a. ed. rev. e ampl. Cotia: Ateliê.

18. . 2013. Matemática dos Afetos: Tratado de (Re)composição Musical. São Paulo: Editora da USP.

19. Moreira, Adriana L. C. 2004. Flashes de Almeida Prado por ele mesmo. Opus. Revista da Associação Nacional de Pesquisa e Pós-Graduação em Música ANPPOM - Ano 10, n. ${ }^{\text {o }}$ 10, p. 73-80.

20. Nadai, Robson A. 2007. Sonata para Trombone e Piano de Almeida Prado: uma análise interpretativa. Dissertação (Mestrado em Música). Campinas: UNICAMP.

21. Persichetti, Vincent. 1985. Armonia del Siglo XX. Madrid: Real Musical.

22. Pousseur, Henri. 2009. Apoteose de Rameau e outros ensaios. Flo Menezes e Mauricio Ayer (trad.). São Paulo: Editora UNESP, 2009.

23. Ramires, Marisa. 2001. A Teoria de Costère: uma perspectiva em análise musical. São Paulo: Embraform.

24. . 2009. Aspectos pioneiros da Teoria de Costère: alguns paralelos com a Teoria dos Conjuntos. In: Anais do Primeiro Encontro de Teoria e Análise Musical. São Paulo: ECA-USP. 
25. Ribeiro, Erika M. 2009. Aspectos interpretativos da Sonata op. 110 de Beethoven. Dissertação (Mestrado em Música). São Paulo: ECA-USP.

26. Sant'Ana, Edson Hansen. 2009. Expressividade intervalar nos poesilúdios de Almeida Prado. Dissertação (Mestrado em Música). Brasília: UNB.

27. Simonsen, Mário Henrique. Tristão e Isolda: Wagner. Disponível em:

http://insightnet.com.br/operasimonsen/img4.pdf. Acesso em: 22/ago/2016.

28. Straus, Joseph N. 2000 (1990). Introduction to post tonal theory. 2a. ed. Upper Saddle River: Prentice-Hall.

29. 2013. Introdução à Teoria Pós-Tonal. Ricardo M. Bordini (trad.)

São Paulo: Editora da UNESP.

30. Toffolo, Rael B. G. 2014. As redes harmônicas de Pousseur aplicadas à composição musical em tempo real. Tese (Doutorado em Música). São Paulo: UNESP.

31. White, Eric W. 1979. Stravinsky: The composer and his works. 2nd ed. Berkeley: California UP.

32. Woolhouse, Matthew. 2012. Wagner in the Round: Using Interval Cycles to Model Chromatic Harmony. Proceedings of the $12^{\text {th }}$ Internacional Conference on Music Perception and Cognition, p. 1142-1145. 